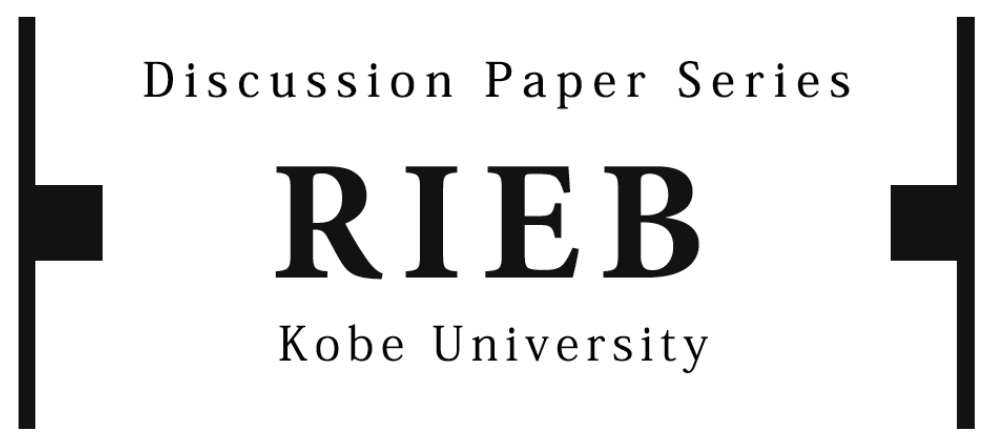

DP2017-24

\title{
Risk-Taking Channel of Unconventional Monetary Policies in Bank Lending
}

\author{
Kiyotaka NAKASHIMA \\ Masahiko SHIBAMOTO \\ Koji TAKAHASHI
}

Revised April 24, 2019

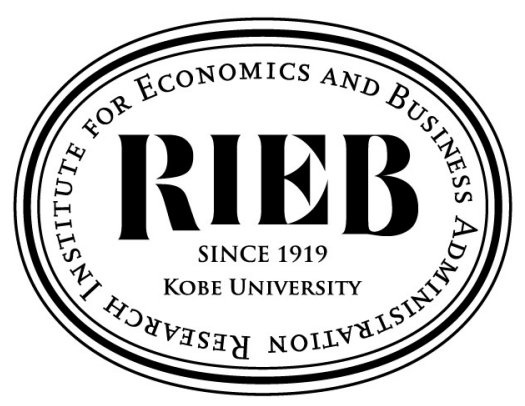

Research Institute for Economics and Business Administration Kobe University 


\title{
Risk-Taking Channel of Unconventional Monetary Policies in Bank Lending*
}

\author{
KiYOTAKA NAKASHIMA ${ }^{\dagger}$ \\ KONAN UNIVERSITY
}

\author{
Masahiko Shibamoto $\ddagger$ \\ KoBe UNIVERSITY
}

KOJI TAKAHASHI $§$

BANK OF JAPAN

March 2019

\begin{abstract}
We investigate the effects of unconventional monetary policy on bank lending, using a bank-firm loan-level matched dataset from 1999 to 2015 by extracting exogenous changes in unconventional monetary policies over the past 20 years in Japan. We find that an increase in the share of unconventional assets held by the Bank of Japan boosts lending to firms with higher credit risks from banks with lower liquidity ratios and higher risk appetites while an expansion of the monetary base does not have such effects. Furthermore, we find that interest rate cuts stimulate lending to risky firms from banks with higher leverage.
\end{abstract}

JEL classification: E44, E52, G21

Keywords: unconventional monetary policy; quantitative and qualitative monetary easing; matched lender-borrower data; risk-taking channel

* The authors would like to thank Kosuke Aoki, Hiroshi Fujiki, James Hamilton, Kimie Harada, Lucas Herrenbrueck, Kaoru Hosono, Kenneth Kuttner, Stephan Luck, Daisuke Miyakawa, Ryuzo Miyao, Ko Munakata, Arito Ono, Rafael Repullo, Hirofumi Uchida, Kenichi Ueda, Wako Watanabe, James Wilcox, Yukihiro Yasuda, and the participants of the 2017 Autumn Meeting of the Japan Economic Association, the 2017 European Meeting of the Econometric Society, the 2018 annual meeting of the Royal Economic Society, the 2018 North American Meeting of the Econometric Society, the Macroeconomic Seminar at the University of Tokyo, and the Kansai Monetary Economics Workshop, for their helpful comments and suggestions. The authors would like to acknowledge the financial support in the form of a Grant-in-Aid received from the Ministry of Education, Science, Sports and Culture. The views expressed here are those of the authors and do not necessarily reflect the official views of the BOJ.

$\dagger$ Kiyotaka Nakashima, Faculty of Economics, Konan University, Okamoto 8-9-1, Higashinada, Kobe, 658-8501, Japan, e-mail: kiyotaka@center.konan-u.ac.jp.

$\ddagger$ Research Institute for Economics and Business Administration, Kobe University, 2-1, Rokkodai, Nada, Kobe, 657-8501, Japan, e-mail: shibamoto@rieb.kobe-u.ac.jp.

$\S$ Correspondence to: Koji Takahashi, Bank of Japan, 2-1-1 Hongokucho, Nihonbashi, Chuo-ku, Tokyo, Zip 103-0021, Japan, e-mail: kouji.takahashi-2@boj.or.jp 
1. Introduction After the 2007-2008 financial crisis, the turmoil in the financial markets and the contraction of the real economy led central banks in developed countries to lower their monetary policy rates effectively to zero. However, the zero lower bound of interest rates hindered the ability of central banks to maintain the inflation rate around the target level or to stimulate the economy. To overcome this situation, central banks introduced unconventional policy measures such as purchasing long-term government bonds and commercial papers as well as introducing negative interest rates on central bank deposits.

Since the introduction of such unconventional monetary policies, a growing strand of the literature has empirically investigated their effects on asset markets and the real economy. ${ }^{1}$ However, the existing literature does not fully examine how such policies affect the real economy in terms of the bank-lending channel. In this study, therefore, we examine whether and how unconventional monetary policy affects bank lending behavior by providing microlevel evidence based on loan-level matched data on Japanese banks and borrowing firms.

Concern about monetary policy's risk-taking channel has arisen given that the period leading up to the 2007-2008 financial crisis was characterized by low monetary policy rates and low inflation in developed countries. The literature on the risk-taking channel has examined the link between conventional monetary policy and banks' excessive risk-taking in lending in the period before the crisis, during which central banks kept their policy rates at low levels to stabilize inflation and output.

Recent theoretical studies including Allen and Gale (2000, 2003, 2007) demonstrate that a lower monetary policy rate plays a critical role in driving excessive leverage and risk-taking in lending to firms with higher credit risks. ${ }^{2}$ In addition, recent evidence supports this theoretical prediction of the effect of conventional monetary policy (Maddaloni and Peydró (2011, 2013), Altunbas et al. (2014), Buch et al. (2014), Jiménez et al. (2014), Ioannidou et al. (2015), and Dell'Ariccia et al. (2017)). ${ }^{3}$

\footnotetext{
${ }^{1}$ See, for example, Joyce et al. (2012) for a survey of empirical research on unconventional policy effects.

2 The Allen and Gale models elucidate the links between a lower monetary policy rate, credit booms, and asset price bubbles due to bank agency problems. Adrian and Shin (2011), Acharya and Naqvi (2012), and Diamond and Rajan (2012) showed the link between conventional monetary policy and excessive risktaking when lending, based on moral-hazard problems. Dell'Ariccia et al. (2014) showed that the effect of changes in policy rates on banks' credit risk-taking depends on the bank's endogenous response to changes in policy rates in terms of leverage; hence, the effect is ambiguous.

${ }^{3}$ See Maddaloni and Peydró (2011), Altunbas et al. (2014), Buch et al. (2014), and Dell'Ariccia et al.
} 
These theoretical and empirical studies warn that easing monetary policy encourages banks to lend more to firms with higher credit risks as well as stimulating the so-called credit channel (i.e., the conventional bank-lending channel) because of bank and firm balance sheet effects. ${ }^{4}$ In contrast to previous research on banks' credit risk-taking under conventional monetary policy, we aim to uncover the channel through which unconventional monetary policy increases banks' credit risk-taking in lending.

This paper contributes to the strand of literature on monetary policy in three main ways. First, we investigate the effects of monetary policy on risk-taking behavior based on the exogenous components of changes in unconventional monetary policy instruments. To our knowledge, no other paper has investigated the heterogeneous effects of unconventional monetary policies on banks' risk-taking behavior by using bank-firm matched data and by directly associating monetary policy shocks with monetary policy instruments. Our paper allows us to obtain policy implications without introducing new policy shocks that are not directly related to policy measures.

Second, we suggest a simple but sufficient approach to extract exogenous policy changes and examine their effects. More concretely, when we extract exogenous components in unconventional policy measures, we take into account the fact that the target levels of unconventional policy measures, in contrast to those of the policy interest rates, are not achieved immediately after the change in policy. This is because, even though central banks including the BOJ and the Fed announce their government-bond purchase schedule on the day of the policy meeting, the observable policy indicator such as monetary base reacts to the change slowly (see Nakashima et al. (2019)). Furthermore, the mechanism by which the unconventional monetary policy affects the economy is ambiguous ex ante. Given these features of unconventional policy measures, imposing plausible restrictions by avoiding misspecification is not a straightforward task. For example, the conventional identification strategies based on a VAR model, including Cholesky decomposition, assume

(2017) for empirical analyses using data from the United States. For a study of the risk-taking channel in the euro area and Spain, see Maddaloni and Peydró (2013) and Jiménez et al. (2014), respectively. Ioannidou et al. (2015) examined the credit risk-taking channel in Bolivia.

${ }^{4}$ Bernanke and Blinder (1988, 1992), Kashyap and Stein (2000), Jiménez et al. (2012), and Drechsler et al. (2017) focused on banks' balance sheet effects while Bernanke and Gertler (1989) put emphasis on firms' balance sheet effects. 
that the path by which unconventional policy shocks affect a variable of interest is fully captured by a VAR system and by historical relationships among variables in the system. Instead of relying on such strict assumptions and identifying the whole system, we directly investigate the effect of unconventional policies on the bank lending by applying an agnostic method proposed by Jordà (2005) and combining annual lending data with high frequency monetary policy shocks. ${ }^{5}$

Third, we exploit bank-firm matched loan data from Japan, where various unconventional policies have been employed for over 20 years and the banking sector has experienced the low interest rate environment. Hence, the interactive effects between monetary policy and banks' risk-taking in Japan provide us with important policy implications not just for Japan, but also for other economies that have implemented unconventional monetary policies since the 2008 financial crisis.

Using Japanese bank-firm matched data, we find that a rise in the share of unconventional assets held by the BOJ increases lending to firms with a lower distance-to-default ratio from banks with lower liquidity ratios and higher risk appetites. By contrast, an increase in the BOJ's balance sheet size does not have such a heterogeneous effect. We also find that interest rate cuts stimulate lending to risky firms from banks with higher leverage ratios and risk appetites. In addition, borrowing interest rates on such risky lending do not necessarily match credit risks of borrowing firms.

The difficulty in identifying the effects of unconventional policy on bank lending mainly arises from the following three factors: how to define monetary policy shocks; how to disentangle such shocks and associate them with monetary policy instruments; and how to pin down the effects of unconventional monetary policies on bank lending. To address the first issue, based on prior literature including Dell'Ariccia et al. (2018) as well as careful observation of monetary policy statements, speeches by MPM board members, and the BOJ's method implementing these policies, in this study, we focus on three types of monetary policy instruments, namely the short-term interest rate, the monetary base, and the composition (unconventional assets ratio) of the central bank's balance sheet. ${ }^{6}$ Although

\footnotetext{
${ }^{5}$ See Section 4 and the online Appendix A for the details of our identification strategy.

${ }^{6}$ In fact, speaking on April 12, 2013, just after the BOJ introduced QQE, Governor Kuroda commented,
} 
previous studies have not fully disentangled the different effects of unconventional policies, it is implausible that a single type of exogenous component in monetary policy would be sufficient to describe the effects of unconventional policies on the economy. ${ }^{7}$ Indeed, changes in the BOJ's balance sheet indicate that unconventional policies are introduced by utilizing various policy instruments simultaneously. Figure 1 shows the year-on-year growth rate of the monetary base (calculated as the log difference multiplied by 100 to show it as a percentage), the ratio of unconventional assets to total assets held by the BOJ, and the policy interest rates (i.e., overnight call rates) from March 1999 to March 2015. This figure illustrates that the policy rate decreased during the early 2000s but showed no change in 2013. It also shows massive growth in the monetary base in the early 2000s, a decline in 2007, and another increase following the implementation of quantitative and qualitative monetary easing (QQE) in 2013. Similarly, note a sharp increase in the ratio of the BOJ's unconventional assets to its total assets in the post-2013 period. Thus, Figure 1 suggests that using only one policy measure is insufficient to capture the effects of unconventional monetary policies.

Previous studies have made several attempts to tackle the difficulty of disentangling the different effects of unconventional monetary policies. For example, the event study approach and the difference-in-differences approach, which are often used to examine the impact of unconventional monetary policy (for e.g., see Gagnon et al. (2011) and Krishnamurthy and Vissing-Jorgenson (2011) for the event study approach, and e.g., Foley-Fisher et al. (2016), Rodnyanski and Darmouni (2017), and Carpinelli and Crosignani (2018) for the differencein-differences approach), do not explicitly disentangle the effects of different policies because some measures are implemented simultaneously in Japan. In addition, even if we exploit financial market information by exploring a high-frequency dataset, these approaches would be insufficient to disentangle the effects of different policies because they do not directly map

\footnotetext{
"Consequently, it becomes important to determine not only how much liquidity to supply but also how to supply that quantity. Even with the same amount of liquidity, purchasing short-term T-Bills produces different effects than in the case where the Bank purchases other assets such as long-term JGBs and risk assets like exchange-traded funds (ETFs). Thus, it is important to work on two aspects of monetary easing, both in terms of quantity and quality."

7 Nakashima et al. (2019) identified one type of conventional policy shock, namely short-term interest rate shocks, and two types of unconventional policy shocks, namely monetary base and composition shocks. See Section 2 for details of the literature on identifying multiple monetary policy shocks.
} 
monetary policy tools onto these extracted shocks. Therefore, obtaining policy implications is difficult if we use only high-frequency data.

To identify monetary policy shocks and map these shocks onto monetary policy instruments, we employ a two-step identification strategy for the exogenous components of monetary policies. We first construct the surprises arising in asset markets following monetary policy meeting days and then associate these surprises with monetary policy tools. By doing so, we extract exogenous policy-induced factors as a response of each policy tool to monetary policy shocks. These exogenous factors are not only plausible measures to address the effects of unconventional monetary policy, but also help shed light on the differences between these measures. Thus, in this study, we investigate the effects of different measures by severally identifying the various unconventional policies employed by the BOJ in the past 20 years.

Finally, to disentangle the risk-taking channel of monetary policy shocks from supply and demand factors, we exploit a matched bank-firm dataset in line with Jiménez et al. $(2012,2014)$, who used loan application data from the Spanish credit register. More specifically, in our main model, we control for the demand and supply effects by using double fixed effects, namely firm*year effects and bank*year effects. Thus, we examine the heterogeneous effects of unconventional monetary policy on bank lending, particularly focusing on the soundness of banks' balance sheets and their aversion to risk.

The remainder of the paper proceeds as follows. Section 2 provides the literature review and discusses the difference between prior studies and this paper. Section 3 introduces the datasets we analyze. Section 4 discusses the exogenous components of monetary policy. Section 5 explains our empirical identification strategy. Section 6 discusses the results, and Section 7 concludes. The companion online Appendix illustrates our strategy for identifying monetary policy shock effects and the estimation results for the double interaction effects of monetary policy and the bank-risk variable, and the estimation results for the probit model for firm bankruptcy to show that distance-to-default predicts firm failure. In addition, the online Appendix reports the estimation results of the probit model, which is used to calculate the inverse Mills ratio to control for the survival bias of bank-firm relationships. 
2. Literature Review By using Japanese data, our study illuminates the risk-taking channel of unconventional monetary policies, as Japan is a leading example of a developed economy with banking sector problems in addition to low interest rates and growth rates. Since the collapse of the bubble economy in the 1990s, the heterogeneity of banks' behavior due to the soundness of their balance sheets has become a central issue in Japan (e.g., Peek and Rosengren (2005) and Caballero et al. (2008)). ${ }^{8}$ In addition to banks' balance sheet problems, the Japanese economy from the 2000s was characterized by extremely low short-term interest rates and low inflation rates under the BOJ's unconventional monetary policy, and accordingly a growing number of studies have investigated the effects of such unconventional monetary policy on the economy. However, the heterogeneous effects of unconventional monetary policy in terms of banks' balance sheet soundness have not been fully studied, with the exception of some works such as Hosono and Miyakawa (2014) and Ono et al. (2016). Hosono and Miyakawa (2014) investigated the bank balance-sheet channel of unconventional monetary policies by using Japanese firm-bank matched loan data and found evidence of the balance-sheet channel. However, they did not extract the exogenous components of unconventional policy measures or consider the slow nature of their responses, whereas we take these into account. Ono et al. (2016) showed that lower long-term yields stimulate bank lending by inducing portfolio rebalancing and easing capital constraints; however, they also did not explicitly identify exogenous unconventional monetary policies.

To our knowledge, Jiménez et al. (2014) and Dell'Ariccia et al. (2017) are the only other studies that have examined the degree to which the relationship between monetary policy easing and credit risk-taking changes with bank capitalization by using a matched bankfirm dataset. Jiménez et al. (2014), for instance, showed that the negative relationship between interest rates and risk-taking in Spain is less pronounced for banks with relatively high capital, while Dell'Ariccia et al. (2017) showed that the negative relationship is more

\footnotetext{
${ }^{8}$ Peek and Rosengren (2005) found heterogeneous lending behavior across Japanese financial intermediaries after the collapse of the bubble economy in the 1990s, motivated by balance sheet cosmetics. Furthermore, Caballero et al. (2008) suggested that such bank lending behavior distorted resource allocation in the economy by helping the survival of zombie firms, which would otherwise be insolvent.
} 
pronounced for those with high capital in the United States. ${ }^{9}$ This previous research has focused only on the links between the monetary policy rate, bank capitalization, and bank risk-taking. In this study, however, we add to the body of knowledge on this topic by analyzing whether and how conventional and unconventional policy easing affects banks' risk-taking depending on the soundness of their balance sheets. ${ }^{10}$

The above empirical studies on banks' risk-taking in lending exploited variations in their financial fragility measured using the leverage ratio or capital adequacy ratio. In other words, they addressed the soundness of banks' balance sheets from the viewpoint of their liability structures. The other strand of the empirical literature on the credit channel has exploited variations in banks' access to liquidity, thereby demonstrating that those with more liquid assets are more likely to increase lending during monetary expansions (Kashyap and Stein (2000) and Campello (2002)). Liquid assets, however, can also be associated with less lending if banks hold liquid assets including Japanese government bonds (JGBs) because of their inclination toward precautionary saving (Almeida et al. (2004) and Dasgupta and Sengupta (2007)). ${ }^{11}$ Therefore, the relationship between liquid assets and banks' risk-taking in lending is ex ante ambiguous. In addition, as Ono et al. (2016) pointed out, the intervention of the BOJ in a financial market such as JGBs has a direct impact on returns and volatility in each market, which in turn induces a change in banks' investment behavior. Hence, the asset compositions of banks serve to generate heterogeneous responses to monetary policy shocks. We thus provide an insight into banks' risk-taking channels by addressing whether and how their asset and liability structures play

\footnotetext{
${ }^{9}$ As in this study, Jiménez et al. (2014) used loan-level lender-borrower matched data and constructed a measure of risk-taking at the firm level. By contrast, Dell'Ariccia et al. (2017) used confidential loan-level data on the internal ratings of US banks and prepared a risk-taking measure at the loan level.However, because the borrower's identity was not disclosed in their data, they did not control for firm characteristics.

${ }^{10}$ While previous research has summarized the risk-taking channel in the context of credit risks, documenting that banks tend to make riskier loans when monetary policy rates are low, some empirical studies focus on financial intermediaries' search for yield mechanisms in the context of duration risk or mismeasurement of credit risks. See, for example, Becker and Ivashina (2015), Chodorow-Reich (2014), and Hanson and Stein (2015) for empirical analyses of US financial intermediaries' search for yields under the Fed's low interest rate policy. In an international context, Bruno and Shin (2015) found that US monetary policy easing increases cross-border banking capital flows as well as the leverage of international banks.

11 Dasgupta and Sengupta (2007) showed that, in a multi-period setting, if firms anticipate being creditconstrained in the future, an increase in liquid balances may make their investment choices more conservative. Empirically, Almeida et al. (2004) found that firms tend to save more during recessions.
} 
a role in their credit risk-taking in the wake of monetary policy easing.

This paper also adds new knowledge to the literature on identifying multiple monetary policy shocks. Few studies have investigated this problem as mentioned in Section 1. For example, Campbell et al. (2012) showed that exogenous factors in the forward guidance of the Fed can be categorized into two types of monetary policy shocks, namely Delphic and Odyssean shocks. Swanson (2018) also investigated the effects of unconventional monetary policy by disentangling large-scale asset purchase shocks from forward guidance shocks. Unlike these studies, we extract exogenous components of monetary policy instruments as responses of such instruments to the policy shocks.

3. Data Sets: Loan-level Matched Data The identification of the effects of unconventional monetary policy on bank lending is hampered by two crucial problems. First, banks of different sizes and with different levels of balance sheet soundness could face different levels of borrower demand; therefore, without bank loans from different banks to the same borrower at the same time, identifying credit supply is impossible. Second, more affected banks may reject more borrowers when monetary policy is tightened, whereas less affected banks could provide more credit, thereby neutralizing the aggregate effects of any credit supply restrictions. Therefore, following Jiménez (2012, 2014), we use a loan-level dataset to overcome these problems.

Our loan-level data comprise a matched sample of Japanese banks and their borrowing firms listed in Japan. We construct our loan-level dataset based on the Corporate Borrowings from Financial Institutions Database compiled by Nikkei Digital Media Inc. This database collects information on the outstanding amounts of bank loans classified by maturity (long-term debt with a maturity of more than one year and short-term debt with a maturity of one year or less) and by bank. We then combine the Nikkei database with financial statement data on Japanese banks and their listed borrowing firms, also compiled by Nikkei Digital Media Inc. ${ }^{12}$

The loan-level dataset includes about 120 banks, 2,000 listed firms, and 17,000 relations

\footnotetext{
12 Although the fiscal year-end for Japanese banks is March 31, this is not necessarily the case for borrowing firms. When combining the Nikkei database with the financial statement data, we thus match bank-side information to borrower-side information in the same fiscal year.
} 
per year for our sample period that runs from fiscal year 1999 to 2014, which covers March 1999 to March 2015. ${ }^{13}$ The reason we use samples only through 2015 is because the BOJ introduced the new negative interest policy framework in February 2016. It is thought that the transmission mechanism of monetary policy could change as the policy rate turns negative (see Eggertsson et al. (2019)). Our dataset covers approximately $65 \%$ of all loans in the Japanese banking sector for our sample period. The number of observations is about 180,000. Table 1 provides the summary statistics for our loan-level matched data.

\section{Identification of Exogenous Unconventional Monetary Policy Identifying the} effects of unconventional monetary policy requires the exogenous components of unconventional monetary policy. ${ }^{14}$ In this section, we illustrate how the exogenous components can be extracted. In the online Appendix A, we rigorously demonstrate that our approach is a plausible way to identify the causal effects of unconventional monetary policy.

Cook and Hahn (1989), Wright (2012), Rogers et al. (2014), and Gertler and Karadi (2015) used high-frequency financial market data to identify exogenous factors in monetary policy as monetary policy shocks, reasoning that a central bank's policy shocks are immediately reflected in asset prices as market participants revise expectations after policy decisions are publicly announced. ${ }^{15}$ If we can correctly obtain the revised expectations of financial market participants induced by a central bank's public statements or participants' surprise over a central bank's policy decisions, we can apply them as instrumental variables to extract exogenous monetary policies from monetary policy measures. The relevant mon-

\footnotetext{
13 See the online Appendix B for the details how to construct bank-firm matched data by taking M\&As into consideration.

14 Jiménez et al. (2012, 2014) examined how monetary policy affects bank lending in Spain. During the period analyzed, monetary policy rates were decided in Frankfurt, not Madrid, assuaging endogeneity in monetary policy. Ioannidou et al. (2015) examined the credit risk-taking channel of monetary policy in Bolivia. They used shifts in the U.S. federal funds rate as a proxy for exogenous changes in Bolivian short-term interest rates because Bolivian banking is effectively dollarized and the U.S. federal funds rate is determined independently of events in Bolivia.

15 From this analytical viewpoint, recent empirical studies have used high-frequency daily trading data to assess the degree to which monetary policy affects asset prices. For example, Kuttner (2001), Cochrane and Piazzesi (2002), Gürkaynak et al. (2005a), Campbell et al. (2012), and Gertler and Karadi (2015) constructed policy surprises in federal funds or one-month euro-dollar futures that occurred on the Federal Fund Open Market Committee (FOMC) meeting dates. To examine the financial market's responses to exogenous monetary policy in Japan, Honda and Kuroki (2006) constructed policy surprises in three-month euro-yen futures that occurred on the BOJ's monetary policy meeting dates.
} 
etary policy measures are the overnight call rate (short-term interest rate), the monetary base, and the composition (unconventional assets ratio) of the central bank's balance sheet. We extract exogenous monetary policies from three monetary policy variables. ${ }^{16}$

4.1. Monetary Policy Surprises To quantify market participants' surprise, we examine changes in asset prices immediately before and after the BOJ's public statements. Previous studies that have employed a high-frequency identification strategy have focused on changes in short-term interest futures; we, however, exploit all information on changes in major financial markets. To this end, we use principal component analysis and extract common factors as suggested by Bernanke et al. (2004), Gürkaynak et al. (2005b), and Swanson (2018). We adopt this approach because short-term rates have hardly changed since the BOJ introduced its unconventional monetary policy.

We examine the surprise of market participants at policy announcements as the common factor underlying unanticipated changes in the major financial market variables following public statements. The principal component analysis of monetary policy on meeting day $t$ is based on the following equation:

$$
\mathbf{X}_{\mathbf{t}}=\Lambda \mathbf{F}_{\mathbf{t}}+\epsilon_{\mathbf{t}}
$$

where $\mathbf{X}_{\mathbf{t}}=\left(x_{1 t}, . ., x_{n t}\right)^{\prime}$ denotes the vector of the $n$ financial time series, $\epsilon_{\mathbf{t}}$ indicates the vector of the $n$ idiosyncratic disturbance terms, $\mathbf{F}_{\mathbf{t}}$ is the vector of the $l$ unobserved common factor, and $\boldsymbol{\Lambda}$ is a matrix of the coefficients identified as factor loadings. We aim to extract common factors $\mathbf{F}_{\mathbf{t}}$ by using the factor model. We include 12 financial market variables $x_{i t}(i=1, . ., 12)$ : one futures rate (three-month euro-yen TIBOR futures), five yen interest swap rates (one-, two-, five-, 10-, and 30-year rates), one short-term spot rate (threemonth euro-yen TIBOR), two spot exchange rates on the Tokyo market (yen-U.S. dollar and yen-AUS dollar), two stock indexes (TOPIX and Nikkei JASDAQ), and banks' reserve deposits. ${ }^{17}$

\footnotetext{
${ }^{16}$ Stock and Watson $(2012 ; 2018)$ and Ramey (2016) surveyed in detail this empirical strategy to identify monetary policy shocks by using monetary policy surprises, namely changes in asset market prices, occurring after central bank public statements.

${ }^{17}$ Here, we take no explicit steps in constructing the monetary policy surprises to control for macroeco-
} 
We calculate the differences in the seven interest rate variables and the log differences of exchange rates, stock indexes, and bank reserves as percentages of the rate of change before and after public statements. More concretely, stock markets close at 3:00 p.m., and the BOJ usually convenes a press conference at 3:30 p.m. after the monetary policy meeting. When calculating changes in the 12 financial variables, we use the closing values of the day before the BOJ's public statements and the opening values of the next day. That is, for stock prices, exchange rates, and bank reserves, $x_{i t}$ is defined as follows:

$$
x_{i t}=\log \left(P_{i t+1, \text { open }} / P_{i t-1, \text { close }}\right) \times 100,
$$

and for interest rates,

$$
x_{i t}=r_{i t+1, \text { open }}-r_{i t-1, \text { close }},
$$

where $P_{i t+1, \text { open }}$ and $P_{i t-1, \text { close }}$ indicate the opening values of exchange rates, stock indexes, and bank reserves of the day after a monetary policy meeting and the closing values of the previous day, respectively. $r_{i t+1, \text { open }}$ and $r_{i t-1, \text { close }}$ denote the opening and closing interest rates.

We preliminarily exclude the dates of meetings at which the BOJ coordinated policy with the Fed, the European Central Bank, or the Bank of England, as well as the dates on which the BOJ agreed on its policy in response to the March 11, 2011 Tohoku earthquake. We do so because policy coordination and disaster response would contaminate the BOJ's policy effects. ${ }^{18}$

To select the number of common factors, we employ the information criteria proposed by Bai and Ng (2002) and Ahn and Horenstein (2013). These tests suggest that the principal

nomic news about real economic activity or inflation in the dynamic factor model. Hence, our monetary policy surprises could include macroeconomic news other than the monetary policy itself. We found, however, that even if we explicitly controlled for macroeconomic news in the construction of monetary policy surprises, estimation results for bank risk-taking were no different from those reported in Section 5. More precisely, we controlled for macroeconomic news on policy meeting days in the factor model, $\mathbf{X}_{\mathbf{t}}=\boldsymbol{\Lambda} \mathbf{F}_{\mathbf{t}}+\boldsymbol{\Gamma} \mathbf{M}_{\mathbf{t}}+\epsilon_{\mathbf{t}}$, where $\mathbf{M}_{\mathbf{t}}$ represents macroeconomic news dummies. We included five news dummies that take a value of one if news about the GDP, unemployment rate, Industrial Production Index, Consumer Price Index, or Producer Price Index is published on policy meeting days.

18 The September 18, 2008, September 29, 2008, and November 30, 2011 BOJ meetings were held to coordinate policy. The meeting on March 14, 2011 agreed on the BOJ's response to the Tohoku earthquake. 
components from the largest eigenvalues are three, and thus endorse adopting three common factors as the monetary policy surprises captured by the 12 financial variables. When constructing monthly data concerning policy surprises, we aggregate the two datasets of the three common factors if the BOJ's monetary policy meeting is held twice in a month. By using the three principal components as instruments, that is, $\mathrm{IV}_{1}, \mathrm{IV}_{2}$, and $\mathrm{IV}_{3}$, we extract the shocks from conventional and unconventional monetary policy measures. ${ }^{19}$

4.2. Exogenous Components of Monetary Policy We use the three principal components as instrumental variables, $\mathrm{IV}_{1}, \mathrm{IV}_{2}$, and $\mathrm{IV}_{3}$, to extract the BOJ's exogenous monetary policies. More specifically, we regress the monthly changes in the three measures (overnight call rates, the monetary base, and the risky asset ratio) on these instrumental variables; thereby, we extract the exogenous component of each policy measure as its response to the monetary policy shocks. This extraction method for measuring exogenous monetary policies is essentially the same as the local projection. In our case, to obtain the exogenous changes in monetary policy measures, we exploit the forecast errors constructed from market-based expectations, that is, $\mathrm{IV}_{1}, \mathrm{IV}_{2}$, and $\mathrm{IV}_{3}$, in our analytical framework (see Jordà (2005) and Stock and Watson (2018) for details on the local projection method). ${ }^{20}$

To extract the responses to the policy measures, we assume that the conventional policy measure - the short-term policy rate - responds immediately to the announcement of a policy change, whereas the unconventional policy measures - the monetary base and the risky assets ratio - do not necessarily. Put differently, an expansionary policy shock leads to an immediate decline in the short-term rate at the time of shock arrival, but a delayed

19 The BOJ's monetary policy meeting is usually held once or twice a month. Each instrumental variable is more precisely defined as follows:

$$
\mathrm{IV}_{k t}=\sum_{h_{t} \in H_{t}} \mathrm{IV}_{k h_{t} t}
$$

where $H_{t}$ indicates the set of days on which the monetary policy meeting is held in month $\mathrm{t}$ and $\mathrm{IV}_{k h_{t} t}$ denotes the principal components of the two-day changes in financial asset prices after these monetary policy meeting days.

${ }^{20}$ As introduced below in equations (4)-(6), our regressions do not include any control variables except for the three principal components since they reflect just the information on randomized policy shocks. However, even if we additionally include other variables, e.g., real GDP and the annual rate of inflation, the resulting exogenous factors in monetary policy are the same as those reported in this section. 
increase in the unconventional policy measures several months after the shock arrival. The assumption for the conventional policy measure is so widely accepted that it allows us to identify the conventional monetary policy shock as an instantaneous unexpected change in the short-term policy rate, e.g., in the VAR literature for the conventional policy effects including Bernanke and Blinder (1992).

The assumption for the unconventional policy measures is based on the fact that when the BOJ implements QQE, on its monetary policy meeting days, it only announces its target level of the BOJ current account balance or the schedule of buying government bonds and risky assets such as ETFs and REITs. Hence, we can observe a gradual increase in the size of the central bank's balance sheet and a gradual change in its composition after the monetary policy meeting (see also Nakashima et al. (2019)). ${ }^{21}$ This fact requires us to consider the unconventional monetary policy shock to the asset market as a type of an announcement shock, but not as a shock that induces immediate responses in the unconventional policy measures at the time of shock arrival. The market reaction, in effect, reflects a prediction about the outcome of targets that will not be attained right after the policy meeting. In other words, even if the monetary base and risky assets ratio change immediately after meeting days, we cannot simply use those changes as exogenous unconventional monetary policies.

In accordance with these assumptions, we construct exogenous components in convenional monetary policy as fitted values generated by the following regression:

$$
\Delta \mathrm{SR}_{t}=\left(\beta_{1 s}+\gamma_{1 s} D_{t}\right) \mathrm{IV}_{1 t}+\left(\beta_{2 s}+\gamma_{2 s} D_{t}\right) \mathrm{IV}_{2 t}+\left(\beta_{3 s}+\gamma_{3 s} D_{t}\right) \mathrm{IV}_{3 t}+\epsilon_{s t},
$$

where $\Delta S R_{t}$ denotes the change in short-term rates in month $t, \mathrm{IV}_{k t}$ denotes the instrumental variables $k$ in month $t$, and $D_{t}$ denotes a dummy that takes 1 after April 2013, when the BOJ introduced QQE, and 0 otherwise. Including the dummy captures the possibility that our instrumental variables exert more effects on the economy because of the commitment and increased credibility of the BOJ's QQE policy. We aggregate the exogenous components, namely the fitted values, for each year to construct the annual data for the

\footnotetext{
${ }^{21}$ Nakashima et al. (2019) demonstrated that the monetary base and composition reach a peak at around 12 and 6 months respectively following a policy shock.
} 
exogenous short-term policy rates.

As for identification of exogenous components in unconventional monetary policy, taking into account the difference between the immediate responses of the asset markets and gradual changes in the unconventional policy measures, we regress the monetary base and risky asset ratio on the lags of our instrumental variables so that the two unconventional measures gradually change over a period of several months after the monetary policy meeting. More specifically, we extract the exogenous components of the monetary base changes as the fitted values obtained by regressing the monthly growth rate in the monetary base on the three-month sums of the instrumental variables as follows:

$$
\begin{array}{r}
\Delta \mathrm{MB}_{t}=\sum_{l=1}^{4}\left(\beta_{1 m l}+\gamma_{1 m l} D_{t}\right) \mathrm{IV}_{1 t}^{l}+\sum_{l=1}^{4}\left(\beta_{2 m l}+\gamma_{2 m l} D_{t}\right) \mathrm{IV}_{2 t}^{l} \\
+\sum_{l=1}^{4}\left(\beta_{3 m l}+\gamma_{3 m l} D_{t}\right) \mathrm{IV}_{3 t}^{l}+\epsilon_{m t}
\end{array}
$$

where $\operatorname{IV}_{k t}^{l}(l=1, . ., 4)$ indicates the three-month sum of instrumental variable $k$ from month $t-3 l+1$ to $t-3(l-1)$. $D_{t}$ denotes a dummy that takes 1 after April 2013, when the BOJ introduced QQE, and 0 otherwise. The reason we include the three-month sums of the instruments rather than directly including their 12th-order lagged variables is that we aim to mitigate the problem of overfitting by reducing the number of instruments and R-squared values in this first-stage instrumental variable regression. ${ }^{22}$ This equation shows that changes in the monetary base occur gradually during the year after the policy meeting, whereas markets immediately respond to policy changes, and the instrumental variables capture such immediate market responses based on market participants' quickly revised expectations.

As in the case of the monetary base, we extract the exogenous components of the composition changes as the fitted values obtained in the following regression:

$$
\Delta \mathrm{COMP}_{t}=\sum_{l=1}^{4}\left(\beta_{1 c l}+\gamma_{1 c l} D_{t}\right) \mathrm{IV}_{1 t}^{l}+\sum_{l=1}^{4}\left(\beta_{2 c l}+\gamma_{2 c l} D_{t}\right) \mathrm{IV}_{2 t}^{l}
$$

\footnotetext{
${ }^{22}$ R-squared values become about $80 \%$ to $90 \%$ when we directly include the 12 th-order lagged variables of the instruments, but they decrease to about $40 \%$ to $50 \%$ when we use the three-month sums.
} 


$$
+\sum_{l=1}^{4}\left(\beta_{3 c l}+\gamma_{3 c l} D_{t}\right) \mathrm{IV}_{3 t}^{l}+\epsilon_{c t},
$$

where the unconventional asset ratio (COMP) is unconventional assets (long-term JGBs, ETFs, stock, REITs, commercial papers, and corporate bonds) divided by total BOJ assets. $^{23}$ We aggregate the fitted values obtained from the instrumental variable regression of the monetary base and risky asset ratio to construct annual data.

Table 2 shows estimation results for instrumental regressions (4)-(6). This table also reports results for a regression of the short-term policy rate with lagged instruments and regressions of the monetary base, and the risky asset ratio with non-lagged instruments to show the contrast between exogenous components in the conventional and unconventional policy measures. Note that since our instrument variables are common factors, estimated coefficients on them cannot provide a direct interpretation about whether and how monetary policy shocks to the asset market increase or decrease each policy measure even though the instruments contain the information on those monetary policy shocks. Nonetheless, those estimated coefficients appear to highlight the validity of our assumption: an instantaneous response of the short-term policy rate and gradual responses of the monetary base and the risky asset ratio.

The regression for the short-term policy rate $\left(\Delta \mathrm{SR}_{t}\right)$ with non-lagged instruments has a significant coefficient at the contemporaneous time of shock arrival $\left(\mathrm{IV}_{3 t}\right.$ and $\left.\operatorname{IV}_{3 t} * D_{t}\right)$. This result is also evidenced for estimated coefficients on $\mathrm{IV}_{3 t}^{1}$ and $\mathrm{IV}_{1 t}^{1} * D_{t}$ in the regression with lagged instruments; however, more importantly, this lagged instrumental regression does not provide any significant coefficient on the second, third, and fourth quarters after the shock arrival. This result suggests that we should extract exogenous components in the short-term policy rate as its instantaneous response to policy shocks, as introduced in equation (4).

By contrast, the regression for the monetary base $\left(\Delta \mathrm{MB}_{t}\right)$ with lagged instruments does not provide any significant coefficient for the first and second quarters after the shock arrival $\left(\operatorname{IV}_{k t}^{1}\right.$ and $\left.\operatorname{IV}_{k t}^{2}(k=1, . ., 3)\right)$, but significant ones for the third and fourth quarters $\left(\operatorname{IV}_{1 t}^{3}\right.$

\footnotetext{
${ }^{23}$ We obtain each item of the unconventional assets from BOJ Accounts.
} 
and $\mathrm{IV}_{1 t}^{4}$ ). Also note that all the interaction terms of non-lagged and lagged instruments with the QQE dummy $\left(D_{t}\right)$ —which takes 1 after April 2013-have significant coefficients, indicating that exogenous components in the monetary base during the QQE period reflect the information on contemporaneous policy shocks as well as lagged ones.

Like the monetary base regression, the regression for the unconventional asset ratio $\left(\Delta \mathrm{COMP}_{t}\right)$ has a significant coefficient on the lagged instrument of the third quarter after the shock arrival $\left(\mathrm{IV}_{3 t}^{3}\right)$, but unlike the monetary base regression, it also has a significant one for the first quarter $\left(\operatorname{IV}_{2 t}^{1}\right)$. Furthermore, the regression for the unconventional asset ratio yields significant coefficients for non-lagged and lagged interaction terms with the QQE dummy, as in the regression for the monetary base. These results indicate that unlike the short-term policy rate, the unconventional policy measures - the monetary base and the unconventional asset ratio - respond gradually following monetary policy shocks. This implies that the central bank's current operations on its balance sheet are affected by previous announcements of the forthcoming expansion of the monetary base and the forthcoming purchases of unconventional assets.

We should note that our estimation methodology — which is based on the immediate response of the short-term policy rate and the slow responses of the monetary base and the unconventional asset ratio - do not exclude the existence of forward guidance (FG) shocks and are consistent with the idea of a rule-based FG proposed by Reifschneider and Williams (2000). More concretely, FG shocks can be reflected in the slow and gradual responses of the two unconventional policy measures, but not in the immediate response of the short-term policy rate. In other words, the BOJ likely changes the unconventional policy measures to demonstrate its commitment to future low policy interest rates. ${ }^{24}$ If FG shocks have effects on banks' behavior, it will be reflected in the effects of changes in the monetary base or unconventional asset ratio in our analysis.

The exogenous component (i.e., fitted value) of the policy measures and their actual changes appear in Figure 2a. The exogenous component of short-term rates plummeted in FY 2001 and FY 2008 when the BOJ lowered its policy rate following the collapse of the

\footnotetext{
${ }^{24}$ By using a non-linear DSGE model with a rule-based FG shock, Katagiri (2016) demonstrates that without FG shocks, inflation rates in the United States would have been much lower in the early 2000s and in the period after the great financial crisis.
} 
Internet bubble and the 2008 financial crisis, respectively. By contrast, 2006 showed an increase in the exogenous components and change in short-term rates when the BOJ began tapering QE. Our strategy of using monetary policy surprises as instrumental variables thus works well to capture shifts in the monetary policy stances of the BOJ, which are reflected in the short-term rates.

The monetary base substantially increased in 2013 when the BOJ increased its balance sheet to achieve its inflation target by introducing QQE. At the same time, the exogenous component of the monetary base increased dramatically, which implies that such a large expansion was surprising for financial markets. The exogenous components of the monetary base also increased in 2001 when the BOJ introduced QE to confront deflation. By contrast, the 2006 decrease in the monetary base was relatively large, while the decrease in its exogenous components was modest. This finding suggests that financial markets somewhat anticipated the onset of tapering.

The exogenous component of the change in asset composition increased substantially in 2001, coinciding with a relatively large increase in the exogenous component of the monetary base. During this period, the BOJ bought more long-term bonds and changed its policy target from overnight call rates to its current account balance. The exogenous component also increased in 2013 after the launch of QQE when the BOJ again bought more long-term bonds and began buying risky assets such as REITs. Our exogenous components for the BOJ's asset composition capture changes in the BOJ's monetary policy scheme.

\subsection{Exogenous Components of Monetary Policy We should also note that Figure} $2 \mathrm{a}$ shows that the BOJ employed different policies contemporaneously. For example, an increase in the risky asset ratio often coincided with an expansion of the BOJ's balance sheet. Our method allows the exogenous components to correlate with each other, although the correlation makes it difficult to understand how each exogenous component affected bank lending.

To overcome this problem, we disentangle each exogenous component by using the Cholesky decomposition. We construct a variance-covariance matrix of the exogenous components (fitted value) and apply the Cholesky decomposition by standardizing their standard deviations as one. When computing the variance-covariance matrix, we arrange 
the exogenous components in the order of short-term rates, monetary base, and unconventional asset ratio, assuming the recursive determination of the policy rate, the size of the BOJ's balance sheet, and its composition. This assumption aligns with the BOJ's aim of implementing QE and QQE. As discussed above, changes in the three policy measures might correlate with each other. Therefore, we expect the exogenous change in size and composition obtained via the Cholesky decomposition to differ from those in the original series.

Figure $2 \mathrm{~b}$ shows the orthogonalized exogenous policy components for the sample period. This figure highlights that the orthogonalized and non-orthogonalized exogenous components, namely the fitted values, of the policy indicators do not necessarily move simultaneously in equal magnitude. The difference is clear in the changes in the unconventional asset ratio and composition shock after the BOJ introduced QQE in 2013. During QQE, the unconventional asset ratio rose but the BOJ's balance sheet also increased significantly. The Cholesky decomposition extracted the exogenous change in the unconventional asset ratio, which is not explained by the increase in size. ${ }^{25}$ In other words, the BOJ intentionally or unintentionally altered the composition of its balance sheet when adjusting its size. Hence, a small change in the exogenous component of the composition would not be identified as an exogenous composition change. Rather, it would reflect only the exogenous change in the monetary base. Therefore, a negative composition change in 2013 indicates that the increase in the composition in 2013 was insufficiently large to be identified as an exogenous composition change. Orthogonalization allows us to examine how independent exogenous changes in the composition affected bank lending. ${ }^{26}$

By using the purely exogenous policy factors corresponding to each monetary policy indicator, the following sections analyze how unconventional monetary policy affected bank lending.

\footnotetext{
25 Note that the decomposition purely depends on the data, which reflect the policymaker's intention and market participants' perceptions of it. The results might change if the BOJ employs a new framework for monetary policy.

${ }^{26}$ A different approach to examine the effects of purchasing unconventional risky assets is to focus on the BOJ's share in each asset market. Li and Wei (2013) investigated the effects of QE in the United States by measuring the share of the Fed's holdings in the U.S. bond market. We disregard this strategy because we investigate the comprehensive effects of increasing the risky asset ratio on bank loans.
} 
5. Econometric Model and Estimation Method In this section, we introduce a loan-level specification of bank lending and then discuss the estimation method to investigate the effects of the monetary policy shocks.

5.1. Loan-level Specification of Bank Lending To exploit our loan-level matched data fully, we employ panel regression with double fixed effects, following Jiménez et al. $(2012,2014)$. In this specification, we control for the borrower and lender effects of unconventional monetary policy, focusing on its heterogeneous credit "allocation" effects owing to the heterogeneity in banks' risk profiles.

Our baseline model with time-variant bank and firm fixed effects is specified as follows:

$$
\begin{aligned}
\Delta \mathrm{LOAN}_{i j t}=\sum_{k=1}^{3}\left(\delta_{k} \mathrm{MP}_{k t} * \mathrm{BANK}_{j t-1} * \mathrm{FIRM}_{i t-1}\right) & +\mathrm{FirmFE}_{i t}+\mathrm{BankFE}_{j t} \\
& +\gamma^{\prime} \mathrm{CONTROL}_{i j t}+\epsilon_{i j t} .
\end{aligned}
$$

where FIRM $_{\mathrm{it}-1}$ is a risky firm indicator that takes one if firm $i$ is categorized as one with high credit risk, and zero otherwise. $\mathrm{BANK}_{j t-1}$ is a proxy for a bank's balance sheet risk or risk-taking stance, such as the leverage ratio or the liquidity ratio. FirmFE $_{i t}$ and BankFE $_{j t}$ indicate the firm and bank fixed effects, respectively. Both fixed effects are interacted with the year dummies, which control for the effects of exogenous monetary policy changes through the borrower and lender factors. CONTROL $_{i j t}$ denotes a vector of the other control variables including the triple interaction terms among a macroeconomic variable (or exogenous monetary policy), a firm variable, and a bank variable to control for the effects of interactions other than those relevant to our interest $\mathrm{MP}_{k t} * \mathrm{BANK}_{j t-1} *$ FIRM $_{i t-1}$. Note that this model does not include variables other than the triple interaction terms because the firm*year and bank*year fixed effects absorb those other variables such as the simple year dummies.

In Equation (7), we address only the heterogeneous policy effects on lending to risky firms ascribed to the heterogeneity in bank's risk compared with those to non-risky firms. This is because the firm*year and bank*year fixed effects absorb and control for the direct and indirect effects of monetary policy through the firm's credit risks and the bank's balance sheet risks. Hence, we can define only the interaction effects involving the triple interaction 
terms. The first derivative with respect to a monetary policy shock is expressed as follows:

$$
\frac{\partial \Delta \mathrm{LOAN}_{i j t}}{\partial \mathrm{MP}_{k t}}=\delta_{k} \mathrm{BANK}_{j t-1} * \mathrm{FIRM}_{i t-1}+\text { others }_{1},
$$

where others ${ }_{1}$ indicates the first derivatives of the other triple interaction terms with respect to the exogenous monetary policy change. We should note that with these time-variant bank and firm fixed effects, we cannot estimate the average effects of monetary policy on bank lending because the time-variant fixed effect terms disappear when we take the derivative of them with respect to exogenous monetary policy changes, although those fixed effects would absorb a large part of the average effects. ${ }^{27}$

When we further take the second derivative with respect to the bank risk variable, the first derivative reduces to the following second derivative:

$$
\frac{\partial^{2} \Delta \mathrm{LOAN}_{i j t}}{\partial \mathrm{MP}_{k t} \partial \mathrm{BANK}_{j t-1}}=\delta_{k} \mathrm{FIRM}_{i t-1}+\text { others }_{2}
$$

where others 2 indicates the second derivatives of the other triple interaction terms with respect to the exogenous monetary policy change and bank risk variable. In the online Appendix $\mathrm{C}$, we also show the estimation results for the double interaction effects with time-variant firm and time-invariant bank fixed effects, although our focus in this paper is on the triple interaction effect.

Finally, if we take the third derivative of the triple interaction term with respect to the exogenous monetary policy change and the bank and firm risk variables, we obtain the triple interaction effect as follows:

$$
\frac{\partial^{3} \Delta \mathrm{LOAN}_{i j t}}{\partial \mathrm{MP}_{k t} \partial \mathrm{BANK}_{j t-1} \partial \mathrm{FIRM}_{i t-1}}=\delta_{k} .
$$

By estimating the interaction effects, we identify the heterogeneous effects of purely exogenous monetary policies $\mathrm{MP}_{k t}$ across the bank risk variable $\mathrm{BANK}_{j t-1}$ on lending to risky firms identified by FIRM $_{i t-1}$. This coefficient has important policy implications as Jimenez

\footnotetext{
27 Nakashima et al. (2019) estimated the average effects of monetary policy on bank lending by identifying unconventional monetary policy shocks as anticipated shocks in a VAR model.
} 
et al. (2014) discussed. For example, suppose that larger bank and firm risk variables mean banks and firms with higher risks, respectively; then, a positive triple interaction effect implies that a bank with higher risk is more likely to increase lending to risky firms compared with lending to non-risky firms in response to an exogenous policy change. In other words, regardless of whether the average effects of the exogenous policy change are positive or negative, the positive coefficient of the triple interaction term indicates that the share of lending to risky firms in the total loans of the bank with higher risk increases more than that for a bank with lower risk in response to the exogenous policy change. ${ }^{28}$ Hence, the triple interaction effect captures the heterogeneous risk profile change in banks' portfolios across those with different degrees of balance sheet risk.

5.1.1. Exogenous Monetary Policies and Interaction Terms Equation (7) has the interaction terms for the exogenous policy changes $\mathrm{MP}_{k t}$. These interactions are the key variables explaining the extent to which unconventional monetary policy heterogeneously affects bank lending. $\mathrm{MP}_{k t}$ denotes one of the three exogenous policy factors, which we obtained from the Cholesky decomposition of the exogenous components of the monetary policy measures in Section 4. Accordingly, we can construct three double interaction terms for each of the bank risk variables with the exogenous components of the three monetary policy measures: the short-term interest rate (SHORT), the monetary base (MB), and the composition (unconventional asset ratio) of the central bank's balance sheet (COMP). Hence we have three triple interaction effects $\left(\mathrm{MP}_{k t} * \mathrm{BANK}_{j t-1} * \mathrm{FIRM}_{i t-1}, k=1,2,3\right)$ in the baseline model (7).

An exogenously positive change in the short-term rate means that the BOJ's increase in nominal overnight call rates exceeded market expectations. Greater exogenous changes in the monetary base mean the BOJ's accommodation of the monetary base. A policy-

\footnotetext{
28 This statement holds even if the double interaction effect of an exogenous policy change and bank risk is negative. The negative double interaction effect means that, in response to a exogenous policy change, banks with higher risk decrease lending equally to risky and non-risky firms more than banks with lower risk do. Then, the positive triple interaction effect implies that banks with higher risk decrease loans to risky firms less than those to non-risky firms, and this difference becomes larger as the bank becomes riskier. Therefore, the share of risky lending for a riskier bank in its total lending increases more than that for a less risky bank. In other words, the triple interaction effect is a key factor to explain the allocation effects of monetary policy.
} 
induced increase in the composition represents an increase in the ratio of the risky assets held by the BOJ.

5.1.2. Firm Credit Risks Jiménez et al. (2014) used a firm's history of defaulting on bank loans to measure the firm's credit risk in their matched lender-borrower sample in Spain. In our matched lender-borrower sample in Japan, however, such loan default data is not available. We thus use distance-to-default as a proxy for firms' credit risk $\left(\mathrm{FIRM}_{i t-1}\right)$ in Equation (7).

Distance-to-default is theoretically derived from Merton's (1974) structural options pricing model. It allows us to incorporate information about a firm's equity, value, and volatility in a theoretically rigorous measure. Distance-to-default has substantial power to predict default and is widely used by banks to manage credit risk. ${ }^{29}$ In fact, in the online Appendix D, we show the estimation results for the probit model for firm bankruptcy, which highlights that distance-to-default significantly predicts a firm's failure.

Distance-to-default is defined as follows:

$$
D D=\frac{\ln \left(V_{A} / D\right)+\left(r-\frac{1}{2} \sigma_{A}^{2}\right)}{\sigma_{A}}
$$

where $V_{A}$ denotes the market value of the borrowing firm, $D$ denotes the book value of its liabilities, $r$ indicates the risk-free rate, and $\sigma_{A}$ indicates the volatility of firm assets. Distance-to-default can be interpreted as the expected standardized difference between the market value of the firm and the book value of its liabilities. If the difference is small (large), a firm is in danger of bankruptcy (healthy). A decrease (increase) in distance-to-default implies greater (smaller) credit risk.

We define the volatility of firm assets $\sigma_{A}$ as $\sigma_{A}=\sigma_{E} \times V_{E} / V_{A}$, where the borrower's market value $\left(V_{A}\right)$ is the sum of the market value of equity $\left(V_{E}\right)$ and book value of total liabilities $(D){ }^{30}$ We calculate the market value of equity by multiplying the stock price

\footnotetext{
${ }^{29}$ Empirical studies that use distance-to-default as a proxy for firm credit risk include Vassalou and Xing (2004), Duffie et al. (2007), and Gilchrist et al. (2009).

30 To compute distance-to-default, we must obtain two unobservable components: the market value of the firm's assets $\left(V_{A}\right)$ and their volatility $\left(\sigma_{A}\right)$. To this end, an iterative procedure is usually adopted to solve the two nonlinear equations derived from the Black-Scholes-Merton formula (Crosbie and Bohn (2003) and
} 
at the end of year $t-1$ by the number of shares. To estimate the volatility of equity $\left(\sigma_{E}\right)$, we calculate the standard deviation for the market value of equity for the final month of a firm's fiscal year and express the estimated volatility as an annual rate. ${ }^{31}$ We use one-year JGBs for the risk-free rate (r).

We rank firms' credit risk by distance-to-default and construct a low distance-to-default indicator for the firm, $\left(\mathrm{FLDD}_{i t-1}\right)$, which takes one if firm $i$ 's distance-to-default at the end of fiscal year $t-1$ is less than the lowest quartile of all observations in the same fiscal year, and zero otherwise. If risk-taking channels of unconventional monetary policy exist, accommodative policy would increase bank loans to firms with higher risks belonging to FLDD4.

As discussed in the Introduction, studies of the credit risk-taking channel have examined lending to firms with high credit risks. In addition, as the Japanese banking crisis in the late 1990s and the 2008 financial crisis in the United States showed, the links between the real estate bubble, credit boom, and accommodative monetary policy have become a central issue for scholars and central bankers (e.g., Hoshi (2001), Gan (2007), and Nakashima and Takahashi (2018a)). To reveal how unconventional monetary policy affects bank lending to the real estate industry, we thus also use a real estate industry dummy (ESTATE) to indicate firm risk instead of low distance-to-default firms, FLDD4.

5.1.3. Banks' Financial Risks We assess the financial soundness and risk aversion of banks by the asset and liability structures of their balance sheets. The liability structure captures financial stability and risk preference, which relate to debt burdens and leverage.

Vassalou and Xing (2004)). Bharath and Shumway (2008) examined the accuracy of distance-to-default and suggested that its functional form, as expressed in Equation (11), matters for forecasting defaults rather than the solution of the two nonlinear equations (see also Duffie et al. (2007)). Our calculation of distance-to-default follows their suggestion.

31 More specifically, we calculate the annualized estimated volatility of the market value of equity as follows:

$$
\sigma_{E, i t}=\sqrt{\frac{1}{D(t)-1} \sum_{d(t)=1}^{D(t)}\left(\operatorname{ret}_{i, d(t)}-\overline{r e t}_{i, t}\right)^{2}} \times \sqrt{D(t)},
$$

where $d(t)(d(t)=1, \cdots, D(t))$ indexes trading days in firm $i$ 's fiscal year $t$. ret $t_{i, d(t)}$ denotes the daily rate of change in equity valuation, and $\overline{r e t}_{i, d(t)}$ is the average rate of change in equity valuation during the fiscal year $t$. 
The asset structure also reflects the soundness of a bank's balance sheet as indicated by its access to liquid assets (i.e., liquidity constraints) in addition to its risk preference. Therefore, we choose a bank risk variable $\left(\mathrm{BANK}_{j t-1}\right)$ based on the characteristics of a bank's asset and liability structures.

Market Leverage Ratio and Nonperforming Loan Ratio Previous studies of Japanese bank lending ascribe its heterogeneity to the soundness of Japanese banks' balance sheets, particularly as measured by capital asset ratios (e.g., Peek and Rosengren (2005), Watanabe (2007), and Caballero et al. (2008)) or non-performing loan ratios (e.g., Hoshi (2001) and Ogawa (2003)). ${ }^{32}$ With regard to a bank's capitalization or liability structure, we measure balance sheet soundness as the market leverage ratio indicating the insufficiency of a bank's equity capital $\left(\mathrm{BMLEV}_{j t-1}\right)$ in our models. The reason we use the market capital measure, and not book capital measures such as the regulatory capital ratio or the book leverage ratio, is partly because book capital measures do not reflect the actual conditions of banks' capitalization (e.g., Haldane (2014), Bulow and Klemperer (2015), Sarin and Summers (2016), and Inoue et al. (2019)), and partly because theoretical studies emphasizing the role of bank capital in its risk-taking deal with the bank capital in market value terms, since market value responds to shocks including monetary policy shocks and thus is more appropriate for analyzing the relationship between banks' leverage and portfolio risks (e.g., Calomiris and Wilson (2004), Adrian and Shin (2011), and Dell'Ariccia et al. (2014)). We define the market leverage ratio as $100 \times \frac{\text { Book Value of Debt }}{\text { Market Value of Equity }+ \text { Book Value of Debt }}$, where the market value of equities is defined as the product of the stock price per issue and the number of stock issues. ${ }^{33}$ In addition to the market leverage ratio, we use the non-performing loan ratio $\left(\mathrm{BNPL}_{j t-1}\right)$ as a proxy for balance sheet soundness. The non-performing loan ratio is the ratio of reported nonperforming loans to total loans.

\footnotetext{
32 According to Watanabe (2007), insufficient capital asset ratios after the collapse of the bubble economy forced Japanese banks to reduce domestic lending. By contrast, Peek and Rosengren (2005) and Caballero et al. (2008) suggested that the unhealthy banks increased lending to low quality firms owing to balance sheet cosmetics, thereby distorting the allocation of credit in Japan.

33 We do not use the distance to default as an equity-based measure of bank default risk. This is because the usual assumption of log-normally distributed asset values in structural models of default risk is not appropriate for banks due to the special nature of their assets. See Nagel and Purnanandam (2018) for details.
} 
The coefficient of the triple interaction terms, for example, for the exogenous composition changes $\left(\mathrm{COMP}_{t} * \mathrm{BMLEV}_{j t-1} * \mathrm{FIRM}_{i t-1}\right)$, would have a positive value if a risk-taking channel exists, because a positive coefficient implies that a bank with low capitalization is more likely to increase (or less likely to decrease) lending in response to an accommodating composition change compared with a bank with high capitalization. ${ }^{34}$ On the contrary, if the response to such a shock equally affected risky lending from both banks with low and high equity capital, the coefficient would be zero, indicating the absence of a risk-taking channel depending on heterogeneities in banks' leverage.

Liquid Assets Ratio Some empirical studies establishing the credit supply effects of monetary policy have emphasized heterogeneities in banks' holdings of liquidity assets (e.g., Kashyap and Stein (2000) and Hosono (2006)) in terms of asset structure. Hence, to investigate whether unconventional monetary policy induces heterogeneous risk-taking behavior by banks depending on their asset structure, we also include interaction terms for the liquid asset ratio $\left(\mathrm{BLIQ}_{j t-1}\right)$, exogenous monetary policy variables, and a firm risk variable. The liquid asset ratio is defined as the ratio of the sum of a bank's cash, deposits, loans outstanding in the call market, and JGB holdings to total book assets. As discussed in the Introduction, the coefficient of the interaction terms for liquid assets and the other components of bank assets with exogenous monetary policies could be positive or negative.

JGB and Stock Holdings Ratios In addition to the liquid asset ratio, we use the ratio of JGB holdings to total assets $\left(\mathrm{BJGB}_{j t-1}\right)$ and stock holdings $\left(\mathrm{BSTOCK}_{j t-1}\right)$. Most JGBs used to be held by Japanese financial intermediaries, including banks, which also have substantial holdings of corporate stocks. Given the fact that the BOJ intervened aggressively in these two financial markets under QQE, the exposures to these two financial markets would directly affect the lending stance of Japanese banks through banks' reachfor-yield behavior and the change in the soundness of banks' balance sheets.

Furthermore, Japanese banks increased JGB holdings to raise their capital adequacy ratio when they promoted the write-off of non-performing loans in the early 2000s. Hence,

\footnotetext{
${ }^{34}$ We should note that positive monetary base and composition changes mean monetary policy easing, while a positive short-term rate change indicates tightening.
} 
banks' investments in JGBs not only become a main source of banks' profits but also reflect their risk aversion. Therefore, a high JGB-holding ratio for a bank implies i) larger capital gains owing to lower interest rates, ii) a low risk appetite, and iii) fewer liquidity constraints. Thus, the coefficient of the triple interaction terms for JGB holdings would also be negative and positive, as discussed for the liquid asset ratio.

A similar argument can be applied to banks' stock holdings. For example, if an increase in banks' capital gains, which stemmed from the BOJ's intervention into the stock markets by increasing its risky asset ratio, stimulated risky lending, a bank with a higher stock holding ratio would respond more significantly to the easing policy. If this was the case, the interaction term with the exogenous composition variable would have a positive coefficient. On the contrary, if the accommodative policy induced reach-for-yield behavior by less risky banks, banks with a lower stock holding ratio might increase riskier lending, which suggests a negative estimate for the triple interaction effects for the exogenous composition variable. Again, the coefficient of the triple interaction term with the bank's stock holdings would be both negative and positive.

By including the asset component variables, we can thus pin down the channel through which unconventional monetary policy affected bank lending most actively. Accordingly, we investigate not only the interaction effects for banks' liquidity constraints, but also those for risk-taking attitude and the direct effects through the financial markets.

5.1.4. Other Control Variables We also include other control variables in the panel regression models. In particular, in addition to the main triple interaction variables $\left(\mathrm{MP}_{k t} *\right.$ BANK $\left._{j t-1} * \mathrm{FIRM}_{i t-1}\right)$ in Equation (7), we include the other eight triple interaction terms between a macroeconomic variable (or a exogenous monetary policy variable), the firm risk variable, and a bank variable as the control variables. As macroeconomic variables, we use the growth rates of the consumer price index and the real GDP from year $t-2$ to $t-1$. As a variable for firm risk, we use the distance-to-default ratio. As a bank variable, we use return on assets $\left(\mathrm{BROA}_{j t-1}\right)$ and bank size $\left(\mathrm{BSIZE}_{j t-1}\right)$ to control for profitability and size. The return on assets is the ratio of net profits to the book value of total assets, and the bank size is defined as a logarithm of the bank's total assets. More concretely, the eight triple interaction terms include two interaction terms comprising one of the two 
macroeconomic variables, a firm's distance-to-default and a bank risk variable, to control for the interaction effects with the macroeconomic environment. The remaining six interaction terms are included to disentangle the interaction effects of monetary policy with the other bank characteristics. Each of them is constructed based on the interaction between one of the three exogenous monetary policy variables, one of the two bank control variables (BROA or BSIZE), and the firm risk variable. In sum, we have eight interaction terms to control for the other interaction effects.

Finally, in Equation (7), all the bank and firm variables and their double interaction effects with exogenous monetary policy variables are excluded because the effects are absorbed by the bank*year and firm*year fixed effects. Thus, we have only the triple interaction terms for the model.

5.2. Correcting for Survivorship Bias Our matched lender-borrower sample is based on a continuation of the lending relationship. According to the literature on relationship banking, the continuation of a bank-firm relationship depends on both the bank's and the firm's characteristics (Ongena and Smith (2001) and Nakashima and Takahashi (2018b)). In other words, we must address the survivorship bias that may arise from non-random assortative matching between banks and firms.

To correct for survivorship bias, we employ Heckman's (1979) two-stage regression technique. The first stage is a probit regression of relationship survival; the second stage is a regression of loan growth based on the estimation method discussed above. To the extent that credit supply/allocation is a two-step process in which a bank first decides whether to lend and then decides how much to lend, the selection model provides an insight into both decisions.

Our probit regression includes one-period lags of four banks' characteristics, such as market leverage ratio, six firms' characteristics, such as interest coverage ratio, and three relationship factors, such as the duration of the relationship between lender $i$ and borrowing firm $j$. We estimate the probit regression for the continuation of bank-firm relationships and then include it to control for survival bias in the bank loan model (7) in the second stage regression. To take into account the possibility that the coefficients of the variables in the probit model are time-varying, as pointed out by Nakashima and Takahashi (2018b), we 
conduct a rolling estimation of the probit model year by year. The details of the estimation results are shown in the online Appendix E.

6. Estimation Results In this section, we discuss the estimation results to provide insight into the extent to which unconventional monetary policy affects Japanese banks' credit risk-taking in lending.

6.1. Risk-Taking Channel and Bank Leverage In this subsection, we report the estimation results of Equation (7) to investigate the extent to which a firm's credit risk matters for banks' risk-taking in response to expansionary monetary policy shocks. Table 3 reports the estimation results obtained by using the FLDD4 dummy variable as the risky firm indicator and the bank market leverage ratio as the bank risk variable.

The triple interaction term comprising the exogenous changes in the short-term interest rate, the bank's market leverage ratio, and bottom one-quarter of firms as ranked by distance-to-default (SHORT $* \mathrm{BCAP} * \mathrm{FLDD} 4)$ has a significantly negative estimate. This result indicates that lowering the short-term rate strongly encourages risk-taking by highly risky banks with relatively high leverage ratios.

The triple interaction term with the exogenous changes in the monetary base (MB) is estimated to be insignificant, suggesting that these policy-induced changes in the monetary base do not have heterogeneous effects on bank lending in terms of bank capital and firm credit risks.

The exogenous changes in the composition (COMP) have insignificant estimates of their triple interaction term with the bank's market leverage ratio (BCAP) and risky firm dummy (FLDD4).

In addition, note that the Inverse Mills ratio has significantly positive estimates, implying that survivorship bias exists in such a way that we would obtain biased estimates for the parameter coefficients without including this ratio.

Summing up, conventional policy easing by lowering short-term interest rates leads to a rise in credit from highly leveraged banks to risky firms compared with those from less highly leveraged banks, while quantitative easing by expanding the monetary base and qualitative easing by increasing the unconventional asset ratio do not. 
6.1.1. Heterogeneous Effects of Bank Assets In this subsection, we explore the heterogeneous effects derived from the composition of bank assets. In particular, we address the interaction effects of banks' liquid assets and exogenous monetary policies on lending by estimating Equation (7). Furthermore, we use other variables related to the main asset components of banks, namely JGBs and corporate equity, as a bank risk variable, to investigate the background mechanism of the effects of exogenous monetary policies.

Bank Liquid Assets The estimation results shown in column (1) of Table 4 are obtained by including the triple interaction terms (MP $*$ BLIQ $*$ FLDD 4$)$ of each exogenous policy variable, the bottom one-quarter of firms by distance-to-default, and the liquid asset ratio in Equation (7) as another bank risk variable instead of the triple interaction effects for the bank market leverage ratio.

Table 4 shows that the interaction term with the bank's liquid asset ratio (SHORT * BLIQ * FLDD4) does not have a significantly negative estimate, implying that banks with more liquid assets are unlikely to increase lending to riskier firms compared with banks with less liquid assets in response to a lowering of the short-term policy rate.

Furthermore, exogenous changes in the monetary base do not have heterogeneous effects on bank lending in terms of bank liquidity. Column (1) of Table 4 indicates that the coefficient of the triple interaction term for the changes in the monetary base, bank liquidity, and firm risk $(\mathrm{MB} * \mathrm{BLIQ} * \mathrm{FLDD} 4)$ has an estimate that is not significantly different from zero.

The triple interaction term for the exogenous change in the composition (COMP $*$ BLIQ $*$ FLDD4) has a significantly negative estimate, indicating that banks with lower liquid asset ratios lend more to risky firms in response to composition changes. This result suggests that increases in the unconventional asset ratio lead to risk-taking behavior by risky banks. Column (1) of Table 4 also provides the magnitude of the interaction effect by showing that a one standard-deviation difference in the liquid asset ratio means a 0.5 percentage point higher increase in risky loans compared to non-risky loans, which is comparable to the effect of the market leverage ratio as shown in Table 3.

Table 4 summarizes our findings that exogenous composition changes are inclined to stimulate lending from banks with lower liquid asset ratios. 
Bank JGB Holdings and Corporate Stock Holdings Ratios To investigate further which components of liquid assets determine the heterogeneous effects on lending, we include a bank's JGB holding ratio (BJGB) instead of its liquid asset ratio as the bank risk variable.

The estimation result shown in column (2) of Table 4 indicates that the triple interaction effect for the exogenous changes in the short-term policy interest rate, the bank's JGB holding ratio, and firm risk (SHORT $* \mathrm{BJGB} * \mathrm{FLDD} 4)$ is estimated to be negative but insignificant. The triple interaction effects for the exogenous components in the monetary base and composition also have negative estimates although they are not significantly different from zero.

We next include the triple interaction effect for the bank's stock holding ratio, a monetary policy variable, and the firm risk variable $(\mathrm{MP} * \mathrm{BSTOCK} * \mathrm{FLDD} 4)$ to address the direct channel through stock markets, in which the BOJ has purchased a substantial number of ETFs under QQE.

Column (3) in Table 4 shows the estimation results, illustrating that none of the interaction terms with the stock holding ratio is significantly different from zero. From this result, we can infer that the main direct channel through which unconventional monetary policies affected bank lending differently was not stock markets. However, we should note that this exercise only examines direct effects through stock holdings. In other words, other paths such as those via the soundness of firms' balance sheets by increasing the firms' capital were not taken into account.

6.1.2. Monetary Policy and the Real Estate Industry In this subsection, we reveal the extent to which unconventional monetary policy affects bank lending to the real estate industry. Therefore, we use the real estate industry dummy variable, ESTATE, instead of low distance-to-default firms, FLDD, as a firm risk indicator.

Column (1) of Table 5 shows that none of the triple interaction terms comprising the exogenous policy changes, banks' market leverage ratios, or the real estate industry dummy have significant estimates.

Following previous studies (Hoshi (2001) and Ogawa (2003)) that have found that the growth rates of loans to the real estate industry by Japanese banks are associated with the 
banks' non-performing loan ratios, we use non-performing loans instead of bank leverage ratio as the bank risk variable. Column (2) of Table 5 indicates that the triple interaction term including the exogenous changes in the short-term policy interest rate and bank's non-performing loan ratios (SHORT $* \mathrm{BNPL} * \mathrm{ESTATE}$ ) has a significantly negative estimate, while the other interaction effects are not significant.

These estimation results imply that monetary policy easing by lowering short-term interest rates induces banks with higher non-performing loans to increase lending to real estate firms more than to non-real estate firms compared with banks that have low nonperforming loan ratios. This finding provides the policy implication that conventional policy easing by lowering short-term rates boosts lending to the real estate industry by financially fragile banks, which might ultimately destabilize the banking system. Furthermore, this increase is not directly associated with the bank's JGB and stock holding ratios because the interaction effect for the short-term interest rate, the JGB holding ratio (or the stock holding ratio), and the real estate industry firm dummy is not significant. ${ }^{35}$

\subsection{Difference in Effects of Each Policy Measure on Bank Risk-Taking Our}

estimation results have thus far shown that the three types of monetary policy measures (i.e., monetary policy rates, the monetary base, and the unconventional asset ratio) affect a bank's lending behavior differently. Here, we discuss some of our insights into the effects of monetary policy on bank risk-taking in lending by showing additional estimation results of models where other bank variables serve as proxies for bank risk preference.

\subsubsection{Effects of Lower Short-term Polcy Rates Even under an extremely low interest} rate regime of unconventional monetary policy, lowering monetary policy rates induces banks with higher leverage ratios to lend more to firms with high credit risks. One possible explanation for such an effect is that lower short-term rates ease banks' capital constraints by increasing their capital gains through the increase in the price of their assets. Another route of the effect related to banks is reach-for-yield behavior, which may arise because banks seek higher yields from securities holdings and lending (i.e., the existence of "yield-

\footnotetext{
35 The estimation results for the coefficient of the triple interaction effects of the JGB and stock holding ratio are not reported in Table 5 .
} 
oriented" banks) as pointed out by Stein (2013). These types of banks have an incentive to increase current yields for institutional or accounting reasons. This tendency can drive banks to invest more in assets and lending that bear higher yields and risks, and it would be observed when the yields of their investment assets and JGBs decrease due to lower monetary policy rates. We examine these two channels, namely the effects of increasing capital gains and reach-for-yield behavior, using different bank risk variables instead of the market leverage ratio.

First, we should note that the heterogeneity in banks' government bond holdings does not have an interaction effect with the exogenous changes in the short-term rate as shown in Table 5. This implies that the heterogeneity in the size of the capital gains brought about by the exogenous policy rate changes does not explain the heterogeneity in the risk-taking behavior by banks in response to such exogenous changes. Put differently, the results in Table 5 suggest that the channel through which conventional monetary policy mitigates bank capital constraints by increasing capital gains due to low interest rates would not be a main driving factor for the risk-taking effects of conventional monetary policy.

Alternative Assets Ratio To address further why lowering short-term rates stimulates lending from risky banks to risky firms, we also use an indicator of banks with high alternative asset ratios, $\mathrm{BHO}_{\mathrm{t}-1}$, as a bank risk variable instead of the bank leverage ratio and estimate the triple interaction effects. The alternative asset ratio is defined as the ratio of the sum of other securities holdings and the absolute value of net derivative position to total assets. ${ }^{36}$

The indicator for banks with high alternative asset ratios is a dummy variable that takes one if the bank's alternative asset ratio is higher than the highest tertile of the samples in each year. A high other asset ratio indicator serves as a proxy for the risk-taking attitude

\footnotetext{
${ }^{36}$ The exposure to the derivative contracts is used to capture off-balance sheet derivative trading activity in the existing literature. For example, Hagendorff et al. (2018) use the log of the ratio of derivative contracts held for trading over total assets to capture the riskiness of banks. Furthermore, Ellul and Yerramilli (2013) point out that this is associated with the bank's risk management. As it is difficult to capture a bank's exposure to derivative contracts from its balance sheet data, we use its net derivative position as a proxy for the exposure. The other securities holdings of banks include foreign bonds and stocks, and domestic and foreign shares in investment trusts, of which the amount held by Japanese banks has increased substantially.
} 
of banks toward off-balance sheet activity and the tendency of banks to seek higher yields in a low interest rate environment. The estimation result shown in Column (1) of Table 6 indicates that the triple interaction effect of the exogenous short-term policy rate changes, the high other asset ratio dummy, and the firm risk variable (SHORT $*$ BHO $*$ FLDD4) has a significantly negative estimate. This result implies that lowering the short-term policy rate increases risky lending from banks with higher other asset ratios more than that from less risky banks. In other words, it suggests lowering the short-term policy rate can stimulate reach-for-yield behavior by risky banks.

High-Risk High-Return Portfolio We also examine whether banks with higher risk appetites tend to increase credit to risky firms in response to exogenous monetary policy changes using the risk profiles of their loan portfolios. In portfolio management, a bank with high risk appetite would prefer a bank loan portfolio that has higher expected returns but is exposed to higher volatility. Given this insight, we construct an indicator of a bank that has a higher return on lending and a higher volatility of the return. More concretely, we construct a dummy variable of banks with high returns and high risks, $B H R H V_{t-1}$, which takes one if the bank's lending returns, defined as the ratio of the interest received from all its loans to its total loans, is larger than the highest tertile in year $t-1$ and the volatility of the returns on bank loans from year $t-5$ to $t-1$ is larger than the median for all banks in year $t-1$, and zero otherwise. Then, we use the high-risk-high-return portfolio bank dummy as a bank risk indicator instead of the bank leverage ratio.

The estimation results in Column (2) of Table 6 show a significantly negative estimate for the triple interaction term for the short-term rate changes (SHORT $*$ BHRHV $*$ FLDD 4 ) and a significantly positive estimate for the composition changes (COMP $*$ BHRHV $*$ FLDD 4$)$, indicating that banks with higher returns on loans and volatility of returns are more likely to increase loans to risky firms in response to a lowering of the short-term rate and an increase in the risky asset ratio. Considering that risk and return have a trade-off relationship in a standard portfolio choice problem, this finding suggests that an exogenous decrease in the short-term rate and an increase in the unconventional asset ratio encourage banks with higher risk appetites to take more credit risks. 
6.2.2. Effects of the Monetary Base Expansion By contrast, exogenous changes in the monetary base do not have heterogeneous effects in terms of the firm's credit risk interacted with the bank's balance sheet and risk preference as shown in Tables 3 to 6 . However, this does not exclude the possibility of its affecting bank lending homogeneously. In fact, in the online Appendix $\mathrm{C}$, we show the estimation result of the double interaction effects of the exogenous change in monetary base and bank leverage, which indicates that an accommodative monetary base change would increase lending from a highly leveraged bank more than that from a less highly leveraged bank. This result concurs with the finding of Baba et al. (2006) that the BOJ's unconventional policy prevented increases in risk premiums in the financial markets, which helped facilitate the funding of Japanese banks. In the context of credit allocation toward risky firms, we find no risk-taking channel of the monetary base.

6.2.3. Effects of Composition Change Exogenous changes in composition lead to an increase in bank loans from banks with low liquid asset ratios and high risk appetites to high-risk firms as shown in Tables 4 and 6. One of the mechanisms of such an effect is that an exogenous increase in the unconventional asset ratio improves the value of bank assets by lowering risk premiums, which eases bank liquidity constraints and causes the heterogeneous effects of monetary policy.

To further address the mechanism that banks with higher risk appetite increase lending to risky firms, we use the loan to deposit ratio as a bank risk variable instead of the bank leverage ratio. The loan to deposit ratio of a bank is defined as the ratio of the bank's total loans to deposit. We should note that Japanese banks basically do not reject deposits from their customers and the deposit is classified as a stable debt for banks. In particular, under a zero lower bound constraint of deposit interest rates, Japanese banks cannot fully control for the amount of deposits. Hence, this ratio reflects the bank's risk-taking attitude toward lending as well as its lending opportunity, compared to its deposits.

As shown in Column (3) of Table 6, the triple interaction effect of the exogenous composition changes, the bank's loan to deposit ratio, and the low distance-to-default firm indicator is estimated to be significantly negative, while the other triple interaction effects for the exogenous changes in the short-term rate and the monetary base are not significantly 
different from zero. This finding suggests that policy-induced changes in the unconventional asset ratio stimulate lending behavior by banks that are taking more risks in lending in terms of the balance between the stable debt and loans. The finding supports that the central bank's purchase of unconventional assets increases risky lending from banks with higher risk appetite, as demonstrated in Tables 4 and 6.

6.3. Loan Pricing and Policy Implications We find a clear distinction among exogenous changes in the three policy measures. Regarding exogenous changes in conventional monetary policy, we find evidence that they stimulate reach-for-yield behavior by risky banks by lowering interest rates and forcing them to invest in assets other than JGBs. Similar to the conventional policy tool, exogenous changes in the composition encourages risk-taking behavior by banks with low liquid asset ratios and high risk appetites. By contrast, exogenous changes in the monetary base do not have heterogeneous effects on risky lending in terms of the leverage and liquidity of bank assets and their risk preference.

Our finding related to the heterogeneous effects of conventional monetary policy on bank lending are in line with the finding of Jiménez et al. (2014), which used Spanish loan registration data when interest rates were well above the effective zero lower bound to show that lowering short-term rates increases risky lending by banks with low capital. Moreover, we extend their finding by illustrating that even in an extremely low interest rate environment, short-term rates have a substantial effect on a bank's risk-taking behavior.

In addition, policy-induced changes in the composition and monetary base have different effects though they are not distinguished well in the literature. One explanation of why changes in the composition alter the behavior of banks with low liquidity and high risk appetite is that these banks interpret those changes as a signal that the central bank is playing a backstop role in bank funding and risky asset markets (Bekaert et al. (2013), Li and Wei (2013), Bauer and Rudebusch (2014), and Munakata et al. (2018)). This signal induces a decline in risk premiums and the volatility of risky assets. ${ }^{37}$ Although it

\footnotetext{
37 Bekaert et al. (2013) found that lax monetary policy decreases risk aversion and uncertainty about stock prices and the former effect is stronger using the VIX. Bauer and Rudebusch (2014) pointed out that the decline in Treasury yields following asset purchase programs might also reflect investor perceptions that monetary policy is to remain accommodative for a longer period than the market previously expected (see also Li and Wei (2013) and Munakata et al. (2018)).
} 
is not theoretically obvious whether this signaling effect affects banks heterogeneously in terms of risky lending, we find empirical evidence that this is the case. In other words, the composition changes allow risky banks to take more credit risks than non-risky banks.

By contrast, increasing the monetary base does not have heterogeneous effects on risky lending by risky banks, partly because it does not have such a strong signaling effect. The reason why an increase in the monetary base does not have effects on risky lending would be that the exchange of money and government bonds does not have a substantial impact on the expected values of risky assets. By contrast, changing the composition of the central bank's assets is a direct signal of the monetary policy stance, which results in risk-taking by risky banks. As QE and QQE policy is designed to lower the risk premiums of risky assets such as stocks, we may conclude that unconventional policy easing by changing the composition ratio of conventional and unconventional assets has the expected effect. However, the resultant distortion in risky asset markets gives rise to the moral hazard of encouraging risky lending by high risk appetite banks (Adrian and Shin (2011) and Jiménez et al. (2014)). Considering our findings, central banks should thus guard against underestimating these side effects of unconventional monetary policy.

In particular, although banks would charge higher interest rates on lending to risky firms, these rates would be insufficiently large to make up for the credit risk that they take. As discussed in Section 5 (see also the result shown in the online Appendix D), the firm risk variable, distance-to-default, significantly affects the probability of firm bankruptcy. However, if we calculate the interest gap following Caballero et al. (2008) and regress it on the low distance-to-default dummy, the coefficient is estimated to be insignificant, as shown in Table $7 .^{38}$ This result suggests that a higher credit risk or a lower distance-todefault is not necessarily associated with higher interest payments. ${ }^{39}$ We should note that our dataset only includes total interest rates on a firm's total debts. Hence, we cannot

\footnotetext{
38 The interest rate gap for a firm is defined as the difference between the firm's actual interest payment and the hypothetical lower bound, which is normalized by the total amount of the firm's borrowing. Total borrowing is calculated as the sum of the outstanding amount of commercial paper, corporate bonds, and bank borrowing. The hypothetical lower bound of interest rate payments in year $t$ is the extremely advantageous rate, which is calculated by using the prime rates for short-term borrowing in year $t$, the average prime rate for long-term bank borrowing from years $t-4$ to $t$, and the minimum rate of convertible bonds issued between years $t-4$ and $t$.

39 Using the distance-to-default instead of its dummy variable does not change the result qualitatively.
} 
conduct a detailed loan-level analysis of interest rates as we did for outstanding amounts of loans. However, the result suggests that risky banks are likely to increase risky lending to exploit only a marginal increase in yields that would not cover the credit risk that they bear. Again, our findings urge policymakers to pay special attention to the side effects of monetary policy in terms of the credit risk-taking channel.

7. Conclusion In this study, we investigated the effects of unconventional monetary policy on bank lending, using a bank-firm matched dataset in Japan from March 1999 to March 2015. From the presented findings, we can draw three conclusions about the bank risk-taking channel under unconventional monetary policy.

First, under an extremely low interest rate regime, lowering short-term interest rates induces banks with higher leverage ratios and higher risk appetites to lend more to firms with high credit risks owing to reach-for-yield behavior, which occurs because of lower yields to maturity.

By contrast, a QE policy of expanding the BOJ's balance sheet does not have heterogeneous effects on risky lending in terms of bank leverage and risk appetite, which implies that the risk-taking channel of policy-induced changes in the monetary base is not effective.

Finally, qualitative easing through the purchase of unconventional assets induces banks with low liquid assets and high risk appetites to increase credit to firms with high credit risks; that is, the bank risk-taking channel works under qualitative easing via banks with high risk appetite. Unlike conventional monetary policy easing, however, unconventional monetary policy does not directly change current short-term rates. Rather, it causes a signaling effect in which the central bank commits to decreasing risk premiums and expected short-term rates, thereby prompting banks with lower liquid assets (i.e., higher risk appetites) to take more credit risks. 
Additional Supporting information may be found in the online version of this article:

Appendix A. Technical Appendix for the Identification of Monetary Policy Effects on Bank Lending

Appendix B. Constructing Bank-Firm Matched Data

Appendix C. Bank Loan Model with Time-Invariant Bank Fixed Effects

Appendix D. Estimation Results for Distance-to-Default and the Probability of Firm Bankruptcy

Appendix E. Estimation Results for Relationship Survival Probability

\section{REFERENCES}

[1] Acharya, V., and H. Naqvi, 2012, The Seeds of a Crisis: A Theory of Bank Liquidity and Risk Taking over the Business Cycle, Journal of Financial Economics, 106, 349-366.

[2] Adrian, T., and H. Shin, 2011, Financial Intermediation and Monetary Economies, In Friedman, B., and M. Woodford, eds., Handbook of Monetary Economics, vol.3. New York: Elsevier, 601-650.

[3] Ahn, S., and A. Horenstein, 2013, Eigenvalue Ratio Test for the Number of Factors, Econometrica, 81, 1203-1227.

[4] Allen, F., and D. Gale, 2000, Bubbles and Crisis, Economic Journal, 110, 236-255.

[5] Allen, F., and D. Gale, 2003, Asset Price Bubble and Stock Market Interlinkage, In Hunter, W., G. Kaufman, and M. Pomerleano, eds., Asset Price Bubbles: The Implications for Monetary, Regulatory, and International Policies. Cambridge: MIT Press.

[6] Allen, F., and D. Gale, 2007, Understanding Financial Crisis, New York: Oxford University Press.

[7] Almeida, H., M. Campello, and M. Weisbach, 2004, The Cash Flow Sensitivity of Cash, Journal of Finance, 59, 1777-1804.

[8] Altunbas, Y., L. Gambacorta, and D. Marquez-Ibanez, 2014, Does Monetary Policy Affect Bank Risk?, International Journal of Central Banking, 10, 95-136.

[9] Baba, N., M. Nakashima, Y. Shigemi, and K. Ueda, 2006. The Bank of Japan's Monetary Policy and Bank Risk Premiums in the Money Market, International Journal of Central Banking, 2, 105-135.

[10] Bai, J., and N. Serena, 2002, Determining the Number of Factors in Approximate Factor Models, Econometrica, 70, 191-221.

[11] Bauer, M., and G. Rudebusch. 2014, The Signaling Channel for Federal Reserve Bond Purchases, International Journal of Central Banking, 10, 233-289.

[12] Becker, B., and V. Ivashina, 2015, Reaching for Yield in the Bond Market, Journal of Finance, 70, 1863-1902. 
[13] Bekaert, G., M. Hoerova, and M. Duca, 2013, Risk, Uncertainty and Monetary policy, Journal of Monetary Economics, 60, 771-788.

[14] Bernanke, B., and A. Blinder, 1988, Credit, Money, and Aggregate Demand, American Economic Review, 78, 435-439.

[15] Bernanke, B., and A. Blinder, 1992, The Federal Funds Rate and the Channels of Monetary Transmission, American Economic Review, 82, 901-921.

[16] Bernanke, B., and M. Gertler, 1989, Agency Costs, Net Worth, and Business Fluctuations, American Economic Review, 79, 14-31.

[17] Bernanke, B., V. Reinhart, and B. Sack, 2004, Monetary Policy Alternatives at the Zero Bound: An Empirical Assessment, Brookings Papers on Economic Activity, 2, 1-100.

[18] Bharath, S., and T. Shumway, 2008, Forecasting Default with the Merton Distance to Default Model, Review of Financial Studies, 21, 1339-1369.

[19] Bruno, V., and H. Shin, 2015, Capital Flows and the Risk-taking Channel of Monetary Policy, Journal of Monetary Economics, 71, 119-132.

[20] Buch, C., M. Eickmeier, and E. Prieto, 2014, In Search for Yield? Survey-based Evidence on Bank Risk Taking, Journal of Economic Dynamics and Control, 43, 12-30.

[21] Bulow, J., and P. Klemperer, 2015, Equity Recourse Notes: Creating Counter-Cyclical Bank Capital, Economic Journal, 125, 131-157.

[22] Caballero, R., T. Hoshi, and A. Kashyap, 2008, Zombie Lending and Depressed Restructuring in Japan, American Economic Review, 98, 1943-1977.

[23] Calomiris, C., and B. Wilson, 2004, Bank Capital and Portfolio Management: The 1930s "Capital Crunch" and the Scramble to Shed Risk, Journal of Business, 77, 421-455.

[24] Campbell, J., C. Evans, J. Fisher, and A. Justiniano, 2012, Macroeconomic Effects of Federal Reserve Forward Guidance, Brookings Papers on Economic Activity, 1, 1-80.

[25] Campello, M., 2002, Internal Capital Markets in Financial Conglomerates: Evidence From Small Bank Responses to Monetary Policy, Journal of Finance, 57, 2773-2805.

[26] Carpinelli, L., and M. Crosignani, 2018, The Eect of Central Bank Liquidity Injections on Bank Credit Supply, mimeo.

[27] Chodorow-Reich, G., 2014, Effects of Unconventional Monetary Policy on Financial Institutions, Brookings Papers on Economic Activity, 1, 155-204.

[28] Cochrane, J., and M. Piazzesi, 2002, The Fed and Interest Rate: A High-Frequency Identification, American Economic Review, 92, 90-95. 
[29] Cook, T., and T. Hahn, 1989, The Effect of Changes in the Federal Funds Rate Target on Market Interest Rates in the 1970s, Journal of Monetary Economics, 24, 331-351.

[30] Crosbie, P., and J. Bohn, 2003, Modeling Default Risk, Research Report, Moody's/KMV Corporation.

[31] Dasgupta, S., and K. Sengupta, 2007, Corporate Liquidity, Investment and Financial Constraints: Implications from a Multi-period model, Journal of Financial Intermediation, 16, 151-174.

[32] Dell'Ariccia, G., L. Leaven, and R. Marquez, 2014, Monetary Policy, Leverage, and Bank Risk Taking, Journal of Economic Theory, 149, 65-99.

[33] Dell'Ariccia, G., L. Leaven, and G. Suarez, 2017, Bank Leverage and Monetary Policy's Risk-Taking Channel: Evidence from the United States, Journal of Finance, 72, 613-654.

[34] Dell'Ariccia, G, P. Rabanal, and D. Sandri, 2018, Unconventional monetary policies in the Euro Area, Japan, and the United Kingdom, The Journal of Economic Perspectives, 32.4, 147-172.

[35] Diamond, D., and R. Rajan, 2012, Illiquid Banks, Financial Stability, and Interest Rate Policy, Journal of Political Economy, 120, 552-591.

[36] Drechsler, I., A. Savov, and P. Schnabl, 2017, The Deposits Channel of Monetary Policy, The Quarterly Journal of Economics, 132, 1819-1876.

[37] Duffie, D., L. Saita, and K. Wang, 2007, Multi-period Corporate Failure Prediction with Stochastic Covariates, Journal of Financial Economics, 83, 633-665.

[38] Eggertsson, G., R. Juelsrud, L. Summers, and E. Getz Wold, 2019, Negative Nominal Interest Rates and the Bank Lending Channel, NBER Working Paper Series, No. 25416.

[39] Ellul, A., and V. Yerramilli, 2013, Stronger Risk Controls, Lower Risk: Evidence from US Bank Holding Companies, Journal of Finance, 68, 1757-1803.

[40] Foley-Fisher, N., R. Ramcharan, and Y. Edison, 2016, The Impact of Unconventional Monetary Policy on Firm Financing Constraints: Evidence from the Maturity Extension Program, Journal of Financial Economics, 122, 409-429.

[41] Gagnon, J., M. Raskin, J. Remache, and B. Sack, 2011, The Financial Market Effects of the Federal Reserve's Large-Scale Asset Purchases, International Journal of Central Banking, 7, 3-43.

[42] Gan, J., 2007, The Real Effects of Asset Market Bubbles: Loan- and Firm-Level Evidence of a Lending Channel, The Review of Financial Studies, 20, 1943-1973.

[43] Gertler, M., and P. Karadi, 2015, Monetary Policy Surprises, Credit Costs, and Economic Activity, American Economic Journal: Macroeconomics, 7, 44-76.

[44] Gilchrist, S., V. Yankov, and E. Zakrajšek, 2009, Credit Market Shock and Economic Fluctuations: Evidence from Corporate Bond and Stock Markets, Journal of Monetary Economics, 56, 471-493. 
[45] Gürkaynak, R., B. Sack, and E. Swanson, 2005a, The Sensitivity of Long-Term Interest Rates to Economic News: Evidence and Implications for Macroeconomic Models, American Economic Review, $95,425-436$.

[46] Gürkaynak, R., B. Sack, and E. Swanson, 2005b, Do Actions Speak Louder than Words? The Response of Asset Prices to Monetary Policy Actions and Statements, International Journal of Central Banking, $1,55-93$.

[47] Hagendorff, J., A. Saunders, S. Steffen, and F. Vallascas, 2018, The Wolves of Wall Street: Managerial Attributes and Bank Business Models, mimeo.

[48] Haldane, A., 2014, Constraining Discretion in Bank Regulation, In: Goodhart, C., D. Gabor, J. Vestergaard, and I. Erturk (Eds.), Central Banking at a Crossroads: Europe and Beyond, Anthem Press, London.

[49] Hanson, S., and J. Stein, 2015, Monetary Policy and Long-Term Real Rates, Journal of Financial Economics, 115, 429-448.

[50] Heckman, J., 1979, Sample Selection Bias as a Specification Error, Econometrica, 47, $153-161$.

[51] Honda, Y., and Y. Kuroki, 2006, Financial and Capital Markets' Responses to Changes in the Central Bank's Target Interest Rate: The Case of Japan, Economic Journal, 116, 812-842.

[52] Hoshi, T., 2001, What Happened to Japanese Banks? Monetary and Economic Studies, 19, 1-29.

[53] Hosono, K., 2006, The Transmission Mechanism of Monetary Policy in Japan: Evidence from Banks' Balance Sheets, Journal of the Japanese and International Economies, 20, 380-405.

[54] Hosono, K., and D. Miyakawa, 2014, Business Cycles, Monetary Policy, and Bank Lending: Identifying the Bank Balance Sheet Channel with Firm-Bank Match-Level Loan Data, mimeo.

[55] Inoue, H., K. Nakashima, and K. Takahashi, 2018, The Emergence of A Parallel World: The Misperception Problem for Bank Balance Sheet Risk and Lending Behavior, mimeo.

[56] Ioannidou, V., S. Ongena, and J. Peydro, 2015, Monetary policy, Risk-taking, and Pricing: Evidence from a Quasi-natural Experiment, Review of Finance, 19, 95-144.

[57] Jiménez, G., S. Ongena, J. Peydró, and J. Saurina, 2012, Credit Supply and Monetary Policy: Identifying the Bank Balance-sheet Channel with Loan Applications, American Economic Review, 102, $2301-2326$.

[58] Jiménez, G., S. Ongena, J. Peydró, and J. Saurina, 2014, Hazardous Times for Monetary Policy: What Do Twenty-Three Million Bank Loans Say About the Effects of Monetary Policy on Credit Risk-Taking?, Econometrica, 82, 463-506. 
[59] Jordà, O., 2005, Estimation and Inference of Impulse Responses by Local Projections, American Economic Review, 95, 161-182.

[60] Joyce, M., D. Miles, A. Scott, and D. Vayanos, 2012, Quantitative Easing and Unconventional Monetary Policy-An Introduction, Economic Journal, 122, 271-288.

[61] Kashyap, A., and J. Stein, 2000, What Do a Million Observations on Banks Say about the Transmission of Monetary Policy?, American Economic Review, 90, 407-428.

[62] Katagiri, M., 2016, Forward Guidance as a Monetary Policy Rule, Bank of Japan Working Paper Series No. 16-E-6.

[63] Krishnamurthy, A., and A. Vissing-Jorgensen, 2011, The Effects of Quantitative Easing on Interest Rates: Channels and Implications for Policy, Brookings Papers on Economic Activity, 42, 215-228.

[64] Kuttner, K., 2001, Monetary Policy Surprises and Interest Rates: Evidence from the Fed Funds Futures Market, Journal of Monetary Economics, 47, 523-44.

[65] Li, C., and M. Wei, 2013, Term Structure Modeling with Supply Factors and the Federal Reserve's Large-Scale Asset Purchase Programs, International Journal of Central Banking, 9, 3-39.

[66] Maddaloni, A., and J. Peydró, 2011, Bank Risk-taking, Securitization, Supervision, and Low Interest Rates: Evidence from the Euro-area and the US lending Standards, Review of Financial Studies, 24, $2121-2165$.

[67] Maddaloni, A., and J. Peydró, 2013, Monetary Policy, Macroprudential Policy and Banking Stability: Evidence from the Euro Area, International Journal of Central Banking, 9, 121-169.

[68] Martinez-Miera, D., and R. Repullo, 2017, Search for Yield, Econometrica, 85, 351-378.

[69] Merton, R., 1974, On the Pricing of Corporate Debt: The Risk Structure of Interest Rates, Journal of Finance, 29, 449-470.

[70] Munakata, K., H. Oi, and Y. Ueno, 2018, Monetary Policy Framework and Information Effect: Evidence from Japanese Data, mimeo.

[71] Nagel, S., and A. Purnanandam, 2018, Bank Risk Dynamics and Distance to Default, mimeo.

[72] Nakashima, K., M. Shibamoto, and K. Takahashi, 2019, Identifying Quantitative and Qualitative Monetary Policy Shocks, mimeo.

[73] Nakashima, K., and K. Takahashi, 2018a, The Real Effects of Bank-Driven Termination of Relationships: Evidence from Loan-Level Matched Data, Journal of Financial Stability, 39, 46-65.

[74] Nakashima, K., and K. Takahashi, 2018b, The Time Has Come for Banks to Say Goodbye: New Evidence on Banks' Roles and Duration Effects in Relationship Terminations, mimeo. 
[75] Ogawa, K., 2003, Economic Analysis of the Great Recession (In Japanese: Daifukyo no Keizai Bunseki), Nikkei Inc., Tokyo.

[76] Ongena, S., and D. Smith, 2001, The Duration of Bank Relationships, Journal of Financial Economics, $61,449-475$.

[77] Ono, A., K. Aoki, S. Nishioka, K. Shintani, and Y. Yasui, 2016, Long-term Interest Rates and Bank Loan Supply: Evidence from Firm-bank Loan-level Data, Bank of Japan Working Paper Series, No.16E-2.

[78] Peek, J., and E. Rosengren, 2005, Unnatural Selection: Perverse Incentives and the Allocation of Credit in Japan, American Economic Review, 95, 1144-1166.

[79] Ramey, V., 2016, Macroeconomic Shocks and Their Propagation, In Taylor, J., and H. Uhlig, eds., Handbook of Macroeconomics, vol.2. New York: Elsevier, 71-162.

[80] Reifschneider, D., and J. Williams, 2000, Three Lessons for Monetary Policy in a Low-Inflation Era, Journal of Money, Credit and Banking, 32, 936-966.

[81] Rodnyansky, A., and O. Darmouni, 2017, The Effects of Quantitative Easing on Bank Lending Behavior, The Review of Financial Studies, 30, 3858-3887.

[82] Rogers, J., C. Scotti, and J. Wright, 2014, Evaluating Asset-Market Effects of Unconventional Monetary Policy: A Cross-Country Comparison, Economic Policy, 29, 749-799.

[83] Sarin, N., and L. Summers, 2016, Understanding Bank Risk through Market Measures, Brooking Papers on Economic Activity, 2, 57-109.

[84] Stein, J., 2013, Yield-Oriented Investors and the Monetary Transmission Mechanism, Remarks at Banking, Liquidity and Monetary Policy, a Symposium Sponsored by the Center of Financial Studies in Honor of Raghuram Rajan.

[85] Stock, J., and M. Watson, 2012, Disentangling the Channels of the 2007-09 Recession, Brookings Papers on Economic Activity, 1, 81-156.

[86] Stock, J., and M. Watson, 2018, Identification and Estimation of Dynamic Causal Effects in Macroeconomics Using External Instruments, Economic Journal, 128, 917-948.

[87] Swanson, E., 2018, Measuring the Effects of Federal Reserve Forward Guidance and Asset Purchases on Financial Markets, NBER Working Paper Series, No. 23311.

[88] Vassalou, M., and Y. Xing, 2004, Default Risk in Equity Returns, Journal of Finance, 59, 831-868.

[89] Watanabe, W., 2007, Prudential Regulation and the Credit Crunch: Evidence from Japan, Journal of Money, Credit and Banking, 39, 639-665.

[90] Wright, J., 2012, What does Monetary Policy do to Long-Term Interest Rates at the Zero Lower Bound?, Economic Journal, 122, 447-466. 


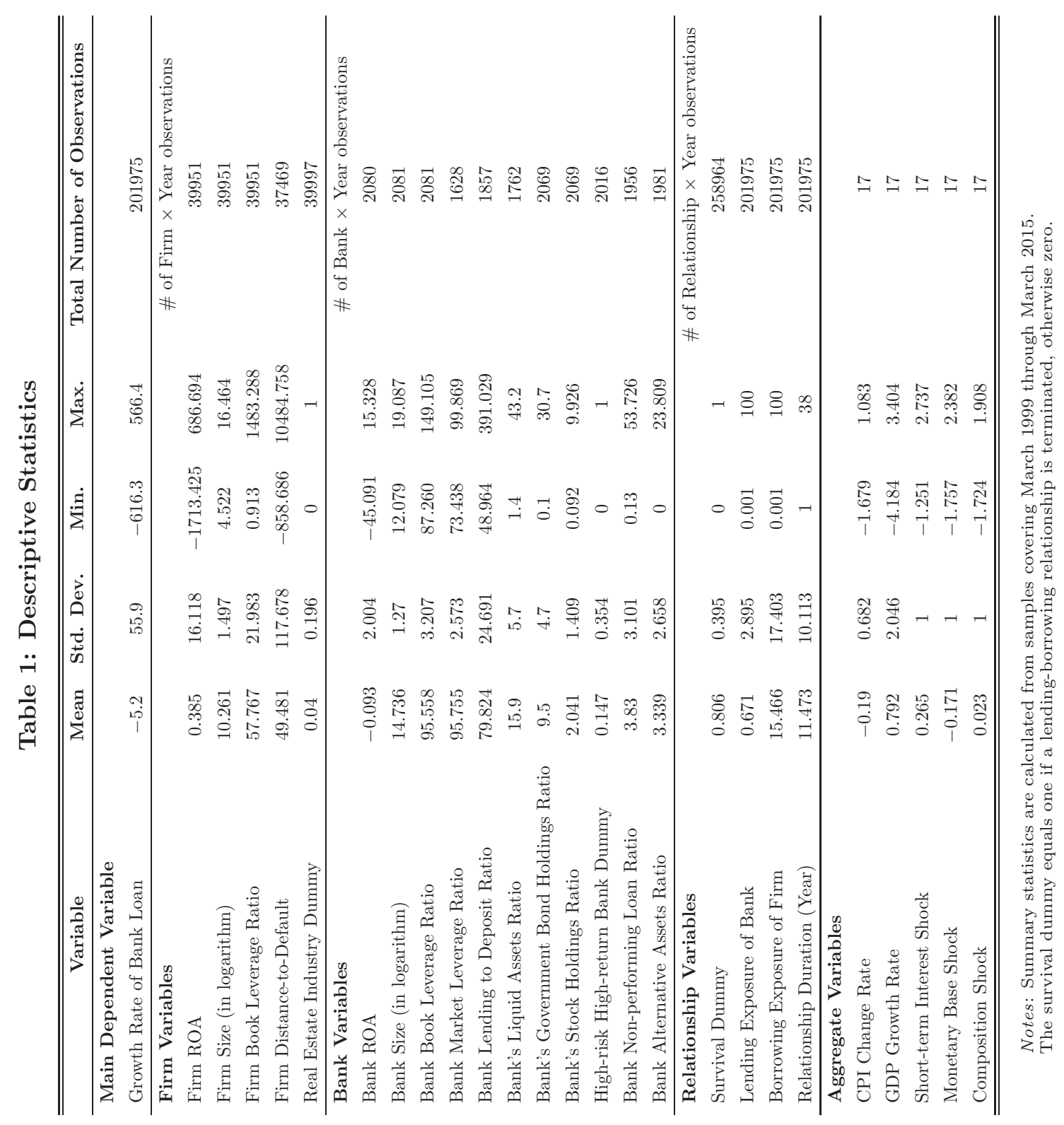


Table 2: Results for Instrumental Variable Regressions

Regressions with Non-Lagged Instruments

\begin{tabular}{lcc|cc|cc}
\hline \hline Dependent Variables & \multicolumn{2}{c|}{$\Delta \mathrm{SR}_{t}$} & \multicolumn{2}{c|}{$\Delta \mathrm{MB}_{t}$} & \multicolumn{2}{c}{$\Delta \mathrm{COMP}_{t}$} \\
\hline Instrumental Variables & & & & & & \\
$\mathrm{IV}_{1 t}$ & -0.014 & $(0.009)$ & -0.027 & $(0.357)$ & -0.002 & $(0.003)$ \\
$\mathrm{IV}_{2 t}$ & 0.004 & $(0.014)$ & 0.192 & $(0.318)$ & $-0.006^{*}$ & $(0.003)$ \\
$\mathrm{IV}_{3 t}$ & $0.063^{* * *}$ & $(0.021)$ & -0.565 & $(0.763)$ & -0.005 & $(0.006)$ \\
\hline \hline $\mathrm{IV}_{1 t} * D_{t}$ & -0.008 & $(0.009)$ & -1.517 & $(1.168)$ & 0.001 & $(0.003)$ \\
$\mathrm{IV}_{2 t} * D_{t}$ & 0.002 & $(0.015)$ & 1.621 & $(1.119)$ & $0.008^{*}$ & $(0.005)$ \\
$\mathrm{IV}_{3 t} * D_{t}$ & $-0.044^{* *}$ & $(0.022)$ & $5.853^{*}$ & $(3.255)$ & 0.010 & $(0.007)$ \\
\hline \hline
\end{tabular}

Regressions with Lagged Instruments

\begin{tabular}{|c|c|c|c|c|c|c|}
\hline Dependent Variables & \multicolumn{2}{|c|}{$\Delta \mathrm{SR}_{t}$} & \multicolumn{2}{|c|}{$\Delta \mathrm{MB}_{t}$} & \multicolumn{2}{|c|}{$\Delta \mathrm{COMP}_{t}$} \\
\hline $\mathrm{IV}_{1 t}^{1}$ & 0.000 & $(0.005)$ & -0.069 & $(0.146)$ & -0.001 & $(0.002)$ \\
\hline $\mathrm{IV}_{2 t}^{1}$ & -0.005 & $(0.007)$ & 0.157 & $(0.195)$ & $-0.005^{* * *}$ & $(0.002)$ \\
\hline $\mathrm{IV}_{3 t}^{1}$ & $0.030^{* *}$ & $(0.013)$ & -0.115 & $(0.317)$ & -0.001 & $(0.003)$ \\
\hline $\mathrm{IV}_{1 t}^{1} * D_{t}$ & $-0.013^{* *}$ & $(0.006)$ & -0.224 & $(0.471)$ & 0.000 & $(0.002)$ \\
\hline $\mathrm{IV}_{2 t}^{1} * D_{t}$ & 0.004 & $(0.008)$ & $1.575^{* * *}$ & $(0.577)$ & $0.010^{* * *}$ & $(0.003)$ \\
\hline $\mathrm{IV}_{3 t}^{1} * D_{t}$ & -0.023 & $(0.015)$ & $4.317^{* * *}$ & $(1.440)$ & $0.010^{* * *}$ & $(0.004)$ \\
\hline $\mathrm{IV}_{1 t}^{2}$ & -0.005 & $(0.004)$ & 0.125 & $(0.170)$ & 0.001 & $(0.001)$ \\
\hline $\mathrm{IV}_{2 t}^{2}$ & -0.004 & $(0.005)$ & 0.136 & $(0.346)$ & 0.002 & $(0.002)$ \\
\hline $\mathrm{IV}_{3 t}^{2}$ & -0.005 & $(0.006)$ & 0.053 & $(0.280)$ & 0.000 & $(0.003)$ \\
\hline $\mathrm{IV}_{1 t}^{2} * D_{t}$ & 0.007 & $(0.005)$ & $-1.749^{* * *}$ & $(0.463)$ & $-0.004^{* *}$ & $(0.002)$ \\
\hline $\mathrm{IV}_{2 t}^{2} * D_{t}$ & 0.003 & $(0.006)$ & 0.520 & $(0.805)$ & 0.001 & $(0.003)$ \\
\hline $\mathrm{IV}_{3 t}^{2} * D_{t}$ & -0.005 & $(0.010)$ & $2.308^{*}$ & $(1.264)$ & 0.005 & $(0.005)$ \\
\hline $\mathrm{IV}_{1 t}^{3}$ & -0.001 & $(0.003)$ & $0.414^{* * *}$ & $(0.140)$ & 0.002 & $(0.002)$ \\
\hline $\mathrm{IV}_{2 t}^{3}$ & -0.003 & $(0.004)$ & 0.140 & $(0.288)$ & -0.001 & $(0.003)$ \\
\hline $\mathrm{IV}_{3 t}^{3}$ & -0.004 & $(0.007)$ & 0.064 & $(0.267)$ & $-0.003^{*}$ & $(0.002)$ \\
\hline $\mathrm{IV}_{1 t}^{3} * D_{t}$ & 0.001 & $(0.006)$ & $-1.364^{*}$ & $(1.209)$ & -0.002 & $(0.004)$ \\
\hline $\mathrm{IV}_{2 t}^{3} * D_{t}$ & 0.007 & $(0.005)$ & $0.965^{*}$ & $(0.780)$ & 0.001 & $(0.003)$ \\
\hline $\mathrm{IV}_{3 t}^{3} * D_{t}$ & 0.004 & $(0.010)$ & $1.879^{*}$ & (1.198) & $0.008^{*}$ & $(0.004)$ \\
\hline $\mathrm{IV}_{1 t}^{4}$ & -0.004 & $(0.004)$ & $0.523^{* * *}$ & $(0.207)$ & -0.001 & $(0.002)$ \\
\hline $\mathrm{IV}_{2 t}^{4}$ & 0.004 & $(0.005)$ & -0.105 & $(0.258)$ & 0.000 & $(0.002)$ \\
\hline $\mathrm{IV}_{3 t}^{4}$ & 0.003 & $(0.006)$ & -0.374 & $(0.367)$ & -0.001 & $(0.003)$ \\
\hline$\overline{\mathrm{IV}_{1 t}^{4} * D_{t}}$ & 0.008 & $(0.006)$ & -0.981 & $\begin{array}{l}(1.073) \\
\end{array}$ & 0.001 & $(0.003)$ \\
\hline $\mathrm{IV}_{2 t}^{4} * D_{t}$ & -0.004 & $(0.006)$ & $2.668^{* * *}$ & $(0.834)$ & 0.001 & $(0.003)$ \\
\hline $\mathrm{IV}_{3 t}^{4} * D_{t}$ & -0.004 & $(0.010)$ & $2.587^{* *}$ & $(1.315)$ & 0.003 & $(0.005)$ \\
\hline
\end{tabular}

Notes: This table shows results for the first stage instrumental variable regressions introduced in Subsection 3.2. The upper panel reports results of regressions with non-lagged instrumental variables, as in regression (4) for the shortterm policy rate $\left(\Delta \mathrm{SM}_{t}\right)$, and the lower panel reports results of regressions with lagged instrumental variables, as in regression (5) for the monetary base $\left(\Delta \mathrm{MB}_{t}\right)$ and regression (6) for the composition $\left(\Delta \mathrm{COMP}_{t}\right)$. ***, **, * indicate $1 \%, 5 \%$ and $10 \%$ levels of significance, respectively. Robust standard errors are in parentheses. 
Table 3: Estimation Result of Baseline Bank Lending Model

\begin{tabular}{|c|c|}
\hline Dep. Variable: $\triangle$ LOAN & Baseline \\
\hline \multicolumn{2}{|c|}{ Exogenous Monetary Policies } \\
\hline SHORT*BMLEV*FLDD4 & $\begin{array}{l}-0.260^{*} \\
(0.151)\end{array}$ \\
\hline MB*BMLEV*FLDD4 & $\begin{array}{c}0.222 \\
(0.229)\end{array}$ \\
\hline COMP*BMLEV*FLDD4 & $\begin{array}{l}0.0342 \\
(0.172)\end{array}$ \\
\hline \multicolumn{2}{|c|}{$\begin{array}{l}\text { Impact of a } 1 \mathrm{St} \text {. Dev. Change in a Monetary Policy Change on } \\
\text { Lending to Risky Firms from Highly versus Lowly Leveraged Banks } \\
\text { (1 St. Dev. Difference) }\end{array}$} \\
\hline Decrease in Short-Term Rate & $0.5 \%$ \\
\hline \multicolumn{2}{|l|}{ Macroeconomic Variables } \\
\hline GDP*BMLEV*FLDD4 & $\begin{array}{c}-0.185^{*} \\
(0.0987)\end{array}$ \\
\hline CPI*BMLEV*FLDD4 & $\begin{array}{l}-0.254 \\
(0.333) \\
\end{array}$ \\
\hline \multicolumn{2}{|l|}{ Other Control Variables } \\
\hline Inverse Mills Ratio & $\begin{array}{l}0.473^{* * *} \\
(0.0214)\end{array}$ \\
\hline SHORT*BROA*FLDD 4 & $\begin{array}{l}-0.708 \\
(0.771)\end{array}$ \\
\hline MB*BROA*FLDD4 & $\begin{array}{c}0.182 \\
(1.056)\end{array}$ \\
\hline COMP*BROA*FLDD 4 & $\begin{array}{l}-1.193 \\
(0.844)\end{array}$ \\
\hline SHORT*BSIZE*FLDD4 & $\begin{array}{l}-0.278 \\
(0.223)\end{array}$ \\
\hline MB*BSIZE*FLDD4 & $\begin{array}{l}-0.0335 \\
(0.235)\end{array}$ \\
\hline COMP*BSIZE*FLDD4 & $\begin{array}{c}-0.738^{* * *} \\
(0.228)\end{array}$ \\
\hline Firm * Year Fixed Effect & $\checkmark$ \\
\hline Bank $*$ Year Fixed Effect & $\checkmark$ \\
\hline$N$ & 169851 \\
\hline
\end{tabular}

Notes: This table shows the estimation results of the bank loan model with firm*year and bank*year fixed effects, where we use the first log-difference of the outstanding amount of bank loan multiplied by 100 as the dependent variable. Each variable denotes a triple interaction term comprised of exogenous monetary policies (or macroeconomic variable), bank covariates, and firm covariates. SHORT, MB, and COMP indicate exogenous components in the short term interest rates, the monetary base, and the composition, respectively. BMLEV indicates bank market leverage ratio. FLDD4 indicates the low distance-to-default firm dummy, where distance-to-default at the end of fiscal year $t-1$ is lower than the lowest quartile of all observations in the same fiscal year. Inverse Mills Ratio is included in the independent variables following Heckman's bias correction procedure to correct for the survival bias of a relationship in our dataset. We excluded some variables from our second stage estimation such as a firm's borrowing exposure from a bank as including these variables did not change our estimation results significantly. ***, ${ }^{*},{ }^{*}$ indicate $1 \%$, $5 \%$ and $10 \%$ levels of significance, respectively. Robust standard errors are in parentheses. 


\section{Table 4: Estimation Results with Bank Assets}

\begin{tabular}{lccc}
\hline \hline Dep. Variable: $\triangle$ LOAN & $(1)$ & $(2)$ & $(3)$ \\
& BANK=BLIQ & BANK=BJGB & BANK=BSTOCK \\
\hline SHORT*BANK*FLDD4 & 0.0112 & -0.0306 & -0.271 \\
& $(0.0489)$ & $(0.0699)$ & $(0.173)$ \\
MB*BANK*FLDD4 & 0.0133 & -0.0310 & 0.271 \\
& $(0.0621)$ & $(0.0651)$ & $(0.281)$ \\
COMP*BANK*FLDD4 & $-0.0862^{*}$ & -0.0970 & 0.263 \\
& $(0.0477)$ & $(0.0693)$ & $(0.192)$ \\
\hline Impact of a 1 St. Dev. Change in a Monetary Policy & & - \\
Change on Lending to Risky Firms from Banks & & - \\
with Low versus High Liquid Assets Ratio (1 St. Dev. Difference) & $0.5 \%$ & $\checkmark$ & $\checkmark$ \\
\hline Firm * Year Fixed Effect & $\checkmark$ & $\checkmark$ & $\checkmark$ \\
Bank Year Fixed Effect & $\checkmark$ & 186909 \\
\hline$N$
\end{tabular}

Notes: Each variable indicates a triple interaction term comprised of exogenous monetary policies, bank covariates and firm covariates. BJGB, and BSTOCK denote Japanese government bond holdings ratio and stock holdings ratio to the bank's total assets, respectively. See notes in Table 3 for definition of the dependent variable $(\triangle \mathrm{LOAN})$, the exogenous monetary policies (SHORT, MB, and COMP), and FLDD4. In the second stage estimation, we include nine control variables as the estimation in Table 3. The estimated coefficients are not reported in the table as the estimation results are not quantitatively different from those shown in Table 3. ***, **, * indicate 1\%, $5 \%$ and $10 \%$ levels of significance, respectively. Robust standard errors are in parentheses.

Table 5: Estimation Results with the Real Estate Industry Dummy

\begin{tabular}{lcc}
\hline \hline & $(1)$ & $(2)$ \\
Dep. Variable: $\Delta$ LOAN & BANK= BMLEV & BANK= BNPL \\
\hline Exogenous Monetary Policies & & \\
SHORT*BANK*ESTATE & -0.385 & $-1.223^{* *}$ \\
& $(0.398)$ & $(0.559)$ \\
MB*BANK*ESTATE & -0.599 & 0.859 \\
& $(0.613)$ & $(0.877)$ \\
COMP*BANK*ESTATE & 0.636 & 0.211 \\
& $(0.516)$ & $(0.629)$ \\
\hline Macroeconomic Variables & & \\
GDP*BANK*ESTATE & $-0.438^{*}$ & -0.0816 \\
& $(0.250)$ & $(0.327)$ \\
CPI*BANK*ESTATE & -0.122 & -0.355 \\
& $(0.897)$ & $(0.900)$ \\
\hline Firm * Year Fixed Effect & $\checkmark$ & $\checkmark$ \\
Bank * Year Fixed Effect & $\checkmark$ & $\checkmark$ \\
\hline$N$ & 169851 & 173048 \\
\hline \hline
\end{tabular}

Notes: The first and second columns specify the estimation result with the bank market capital and bank nonperforming ratio, respectively as a bank risk variable. BNPL indicate the non-performing loan ratio, expressed in percentage terms. See notes in Table 3 for definition of the dependent variable ( $\triangle$ LOAN) and the exogenous monetary policies (SHORT, MB, and COMP). In the second stage estimation, we include inverse Mills ratios and the six triple interaction terms as the estimation in Table 3. The estimated coefficients are not reported in the table. ***, **, * indicate $1 \%, 5 \%$ and $10 \%$ levels of significance, respectively. Robust standard errors are in parentheses. 
Table 6: Estimation Results with High Alternative Assets Ratio Banks

\begin{tabular}{lccc}
\hline \hline Dep. Variable: $\triangle$ LOAN & BANK= BHO & BANK=BHBRHV & BANK $=$ BLD \\
\hline Monetary Policy Interaction Terms & & & \\
SHORT*BANK*FLDD4 & $-1.250 * *$ & $-2.154^{*}$ & $(0.0100)$ \\
& $(0.584)$ & $(1.183)$ & -0.00543 \\
MB*BANK*FLDD4 & 0.507 & -0.229 & $(0.0116)$ \\
& $(0.721)$ & $(0.949)$ & $0.0137^{*}$ \\
COMP*BANK*FLDD4 & 0.0380 & $1.596^{* *}$ & $(0.00749)$ \\
\hline Firm * Year Fixed Effect & $(0.584)$ & $(0.744)$ & $\checkmark$ \\
Bank $*$ Year Fixed Effect & $\checkmark$ & $\checkmark$ & $\checkmark$ \\
\hline$N$ & $\checkmark$ & $\checkmark$ & 173203 \\
\hline \hline
\end{tabular}

Notes: This table shows the estimation results of the bank loan model with firm*year and bank*year fixed effects. Each variable indicates a triple interaction term comprised of monetary policy shocks, bank covariates and firm covariates. BHO indicates the high alternative assets ratio bank dummy, where the bank's ratio of the other securities holdings and the absolute value of net derivative position to total assets in year $t-1$ is bigger than the highest tertile of all observations in each year $t-1$. BHRHV indicates the high-risk high-return bank indicator, where the bank's return on lending in year $t-1$ is bigger than the median and the volatility of the return from $t-5$ to $t-1$ is bigger than the highest tertile of all observations in each year $t-1$. BLD indicates the bank's loan to deposit ratio. See notes in Table 3 for definition of the dependent variable $(\triangle \mathrm{LOAN})$, the exogenous monetary policies (SHORT, MB, and COMP), and FLDD4. For other control variables in the second stage estimation, see notes in Table 3. ***, **, * indicate 1\%, $5 \%$ and $10 \%$ levels of significance, respectively. Robust standard errors are in parentheses.

Table 7: Estimation Result for Interest Rate Gaps Regression

\begin{tabular}{lc}
\hline \hline Dependent Variable: & Interest Rate Gap $t$ \\
\hline FLDD4 & -0.00110 \\
& $(0.00141)$ \\
\hline$N$ & 35440 \\
\hline \hline
\end{tabular}

Notes: The regression model is as follows:

$$
\mathrm{GAP}_{i t}=\beta \mathrm{FLDD}_{i t}+\mathrm{YearFE}_{t}+e_{i t},
$$

where $e_{i t}$ denotes a disturbance term. The dependent variable $\left(\mathrm{GAP}_{i t}\right)$ is the firm's interest rate gap calculated following the method used by Cabarello et al. (2008). The independent variables consist of the low distance-to-default indicator $\left(\mathrm{FLDD}_{i t}\right.$ ) and the year dummies (YearFE $\mathrm{F}_{t}$. See notes in Table 3 for for definition of FLDD4. Using the firm's distance to default instead of FLDD4 does not change the result qualitatively. Including other control variables such as industry dummies and other firm covariates does not change the result qualitatively. ***, **, * indicate $1 \%$, $5 \%$ and $10 \%$ levels of significance, respectively. Standard errors are in parentheses. 
Figure 1: Monetary Base, Unconventional Assets and Call rate

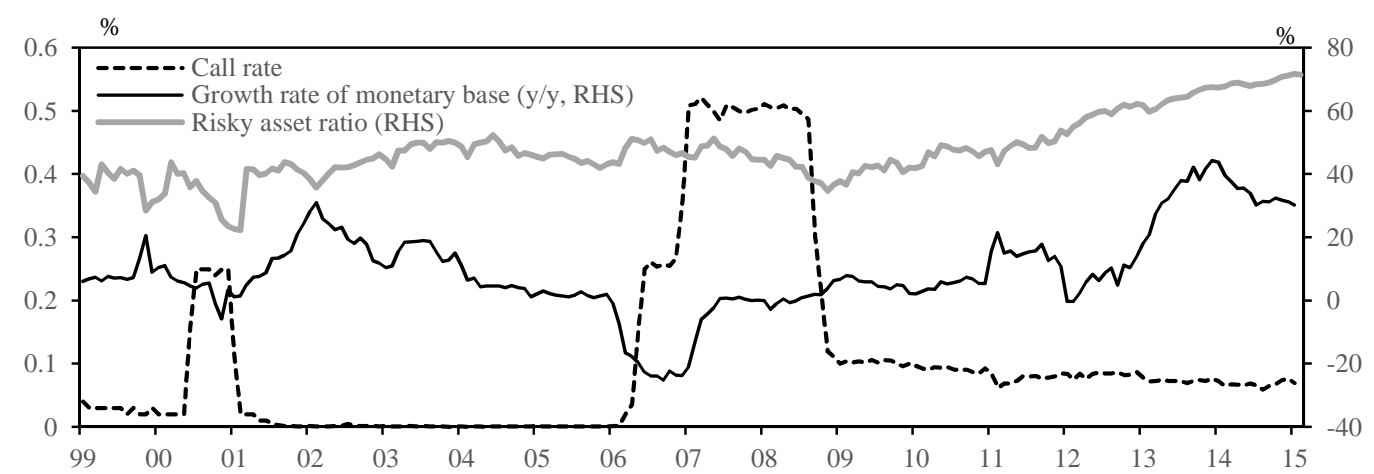

Notes: The dark gray line indicates the ratio of unconventional assets to the total asset held by the Bank of Japan shown on a percentage basis. The black solid line indicates year-on-year growth rate of monetary base, which is calculated as the log-difference, shown on a percentage basis. The dotted line indicates the call rate in percentage on the left-vertical axis. Unconventional Assets include the exchange-traded fund (ETF), real estate investment trust (REIT), corporate bonds, commercial papers, long-term government bonds, and asset backed securities. Conventional assets include other assets such as short-term government bonds.

Figure 2a: Exogenous Components of Monetary Policy Instruments
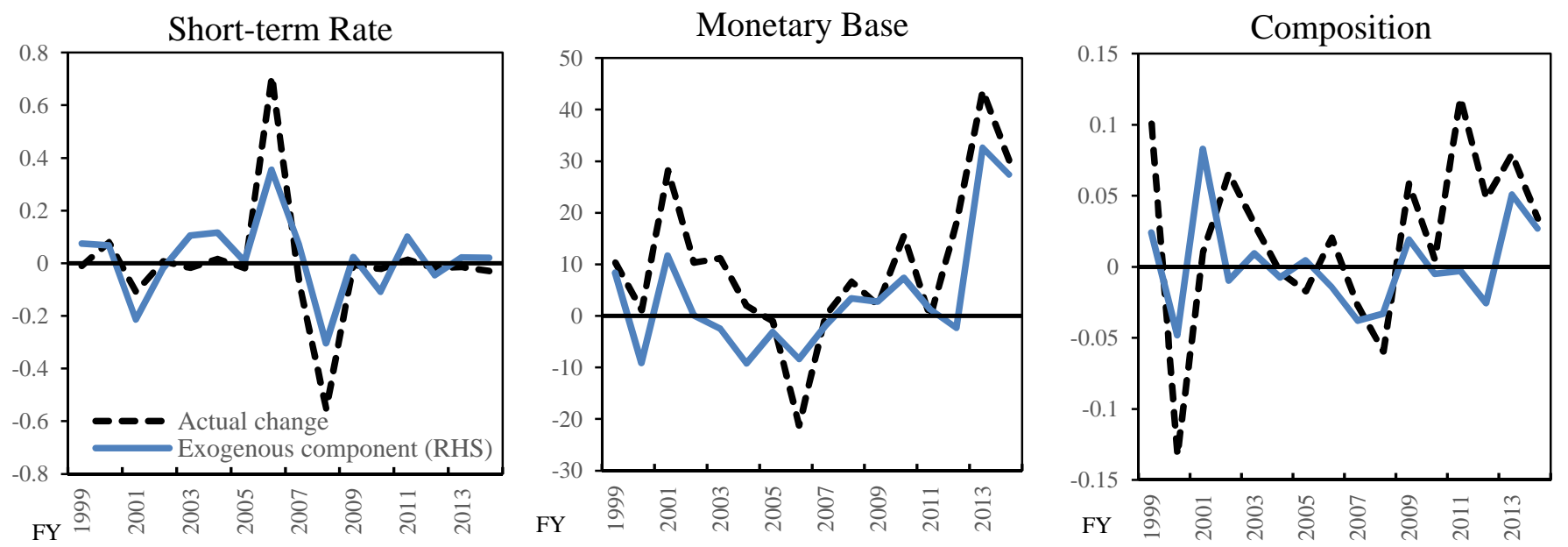

Figure 2b: Monetary Policy Shocks
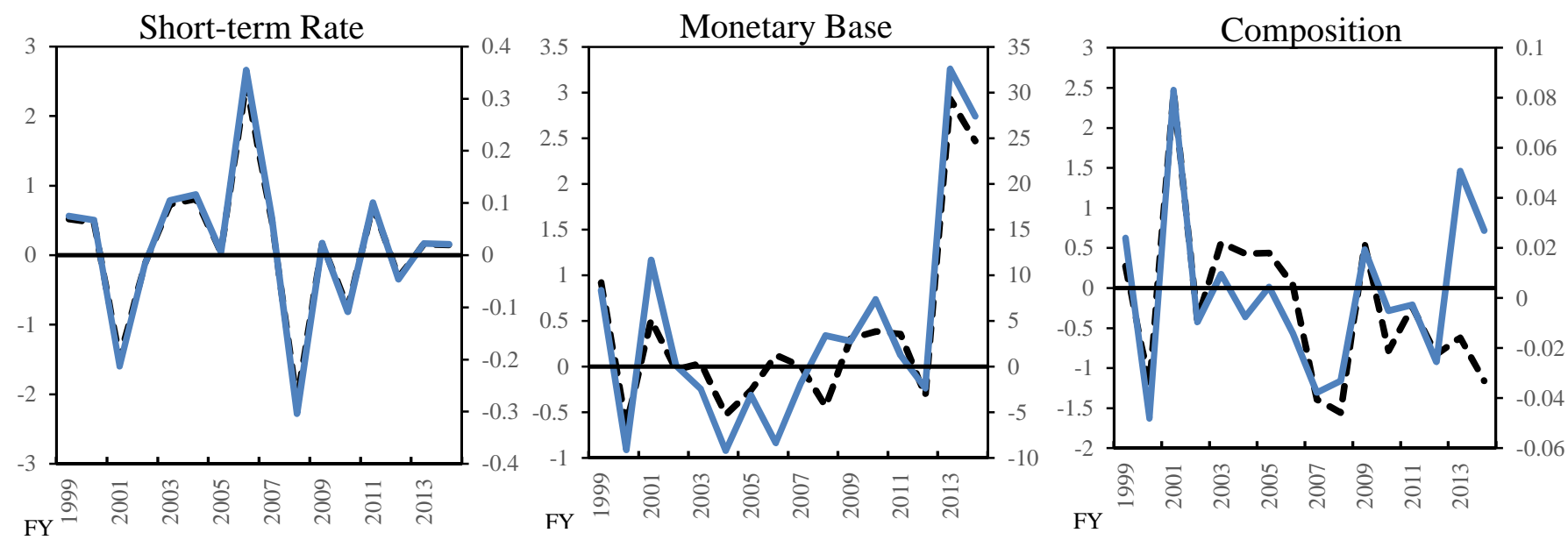

- - Orthogonalized Shock

Exogenous component (RHS)

Notes: Exogenous components of short-term rates are obtained by regressing monthly changes in the short-term rates on unexpected contemporaneous monetary policy surprises, which are used as instrumental variables. These surprises are extracted as three principal components from prices and rates changes of twelve financial assets immediately before and after public announcements on monetary policy meeting days. Exogenous components of composition and monetary base are obtained by regressing monthly changes in risky asset ratio and monetary base on the 1--4 quarterly lagged monetary policy surprises, respectively. Each series is summarized on a fiscal year basis. In Figure 2b, short-term rate, monetary base, and composition shocks are obtained by implementing Cholesky decomposition on fitted values of those measures, which are obtained by using three monetary policy surprises as instrumental variables. 